\title{
Metallomics
}

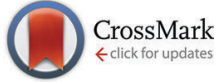

Cite this: Metallomics, 2015 7, 371

Received 26th September 2014 Accepted 8th January 2015

DOI: 10.1039/c4mt00255e

www.rsc.org/metallomics

\section{Vesicular disruption of lysosomal targeting organometallic polyarginine bioconjugates $\dagger$}

\author{
Annika Gross, $\neq^{\star^{a}}$ Hamed Alborzinia, ${ }^{b}$ Stefania Piantavigna, ${ }^{c}$ Lisandra L. Martin, ${ }^{c}$ \\ Stefan Wölfl ${ }^{b}$ and Nils Metzler-Nolte*a
}

Compounds which are able to destabilize the lysosomal membrane have been proposed as interesting candidates for targeted anticancer drugs due to the pronounced lysosomal changes in cancer cells. For this purpose, metallocene derivatives of a cell penetrating polyarginine peptide $\mathrm{M}-(\mathrm{Arg})_{9}(\mathrm{Phe})_{2} \mathrm{Lys}-\mathrm{NH}_{2}$ (where $M=$ ferrocene carboxylate or ruthenocene carboxylate) were designed and their biological activities were investigated in detail. The ferrocenoyl- and ruthenocenoyl polyarginine bioconjugates were synthesized via Fmoc solid-phase peptide synthesis (SPPS) protocols on a microwave-assisted synthesizer. After HPLC purification $>98 \%$ purity was observed for all conjugates. Their interaction with supported biomimetic membranes was investigated on a quartz crystal microbalance (QCM) and revealed a very strong binding of the metallocene peptides and their metal-free congeners to an artificial eukaryotic membrane model (DMPC-cholesterol). To demonstrate their antiproliferative utility as cytotoxic compounds for a targeted anticancer drug, cell viability (by the crystal violet assay), apoptosis (flow cytometry, Ann V/PI staining), induction of reactive oxygen species (ROS, by flow cytometry with dihydroethidium staining), and changes in cancer cell metabolism, e.g. respiration and glycolysis, were studied. Our results reveal only a weak toxicity for the metal-free polyarginine peptide, which could be significantly enhanced (to ca. $50 \mu \mathrm{M}$ against HeLa cells in the best case) by coupling ferrocene or ruthenocene carboxylates to the $\mathrm{N}$-terminus of the peptide. The investigation of the cellular uptake and intracellular localization by fluorescence microscopy revealed an enhanced vesicular disruption by the metallocene bioconjugate compared to the metal-free derivative which could be triggered by light and chemicals. Further studies of apoptosis, respiration, glycolysis and ROS formation reveal the superior characteristics of the metallocene compounds. While most cells remain viable even at $300 \mu \mathrm{M}$ of the metal free bioconjugate 1 , most cells are dead or in late stages of apoptosis at $200 \mu \mathrm{M}$ of the ruthenocene derivative 3 , and at $100 \mu \mathrm{M}$ of the most active ferrocene derivative 2, however, all show very little sign of necrosis. Also, the metal free compound 1 does not induce ROS formation but both metallocene-polyarginine bioconjugates are clearly associated with enhanced intracellular ROS levels, with levels for the redox-active ferrocene derivative being two times higher than for the structurally very similar but redox-silent ruthenocene derivative. We propose that such metallocene-polyarginine peptides induce lysosomal membrane permeabilization and thereby could be developed towards targeted anticancer drugs.

\footnotetext{
${ }^{a}$ Department of Chemistry and Biochemistry, University of Bochum, Universitätsstrasse 150, D-44801 Bochum, Germany.

E-mail: Nils.Metzler-Nolte@ruhr-uni-bochum.de,Annika.Gross@ruhr-uni-bochum.de; Fax: +49 (0)234-32 14378; Tel: +49 (0)234 3228152

${ }^{b}$ Institute of Pharmacy and Molecular Biotechnology, Ruprecht-Karls-Universität Heidelberg, Im Neuenheimer Feld 364, D-69120 Heidelberg, Germany

${ }^{c}$ School of Chemistry, Monash University, Clayton, Victoria, Australia

$\dagger$ Electronic supplementary information (ESI) available: HPLC chromatograms of chosen compounds (1, 2, 3 and 5) Fig. S1, membrane studies Fig. S2-S4, cellular uptake data of 4, 5 and 6 in PT45 cells Fig. S5, resazurin assay of 1, 2 and 3 Table S1, apoptosis study S6, cell cycle experiment S7 and abbreviations. See DOI: $10.1039 / \mathrm{c} 4 \mathrm{mt} 00255 \mathrm{e}$

‡ Current address: Institute of Pharmacy, Technische Universität Braunschweig, Beethovenstr. 55, D-38106 Braunschweig, Germany.
}

\section{Introduction}

Lysosomes are important intracellular vesicles responsible for degradation of cellular components. They maintain a lower $\mathrm{pH}$ than the rest of the cell, and contain numerous hydrolytic enzymes such as hydrolases, peptidases, phosphatases, and cathepsins. For a long time, lysosomal membrane permeabilization (LMP) was only known to release hydrolases in an unspecific manner, resulting in uncontrolled necrosis. More recently, it was established that this is valid only in the case of massive lysosomal leakage, whereas minor leakage seems to be an important part of the apoptotic pathway. ${ }^{1}$ Therefore, targeting of lysosomes was proposed as an interesting, novel pathway for 
cancer therapy. Controlled LMP is capable to either initiate early events of cell death by releasing cathepsins, or to amplify later events in the apoptotic pathway by modulation of various apoptotic stimuli, including death receptor activation. ${ }^{2}$ Also, reactive oxygen species (ROS) play an important role since they lead to membrane destabilization via peroxidation of membrane lipids. Alternatively, modification in the intracellular redox balance may start a redox-dependent signaling cascade, again resulting in LMP. ${ }^{2}$ Iron complexes or iron-containing proteins increase lysosomal vulnerability, ${ }^{3-7}$ and furthermore, changes in the membrane structure may lead to a revised fluidity, which can result in lysosomal destabilization. ${ }^{8-12}$ In terms of therapeutic potential, lysosomotropic detergents - i.e. basic compounds that accumulate in acidic lysosomes and disrupt them from within were considered as putative anticancer drugs. ${ }^{1}$ Cancer cells and particularly multidrug-resistant cancer cells may be targeted by this method, ${ }^{1}$ due to their strong lysosomal changes which are associated with invasive growth and angiogenesis in cancer cells. ${ }^{13,14}$ However, these changes of the lysosomes for example in expression and activity of lysosomal cysteine cathepsins correlate with the metastatic capacity and aggressiveness of tumors and should sensitize cells to the lysosomal cell death pathway even when apoptosis is inhibited. ${ }^{15}$

For our studies we assumed that basic polyarginine peptides, also known as cell-penetrating peptides (CPP), might be capable of targeting lysosomes and inducing LMP. ${ }^{16-18}$ CPPs are artificially designed peptides or variegated sequences based on natural peptides or proteins to guide a wide variety of cargoes into living cells. ${ }^{19-21}$ Polyarginine peptides can enter cells in a receptor-independent way, gaining access into nearly all types of cells and tissues. This propensity has made them optimal tools to deliver molecular cargoes into cells. The mechanism is not known in detail, ${ }^{22,23}$ but one possible mode of action is the interaction of the cationic peptide with the cell surface glycosaminoglycans, followed by an energy dependent cellular uptake mechanism, probably via endocytosis. In live cell experiments endocytotic vesicles are visible. To escape the vesicles, heparan sulfate proteoglycans have to be degraded by heparanases to free the peptide. ${ }^{24}$ The basic nature of polyarginines makes them promising candidates for LMP. This study was designed as a first step to test such assumptions, with the purpose of further developing such peptides and their derivatives as anticancer drugs in the future.
Since iron compounds were able to enhance vesicular disruption $^{3-7}$ we were interested in the effect of metallocenes, especially ferrocene, linked to the basic peptide polyarginine for the purpose of lysosomal disruption towards anticancer therapy. Recently, organometallic compounds have attracted great attention and their applications in medicinal chemistry have been reviewed. ${ }^{25-27}$ Ferrocene is the by far most important and most investigated metallocene in medicinal chemistry. ${ }^{28-30}$ It is very stable towards air and water, which makes it an ideal workhorse within a biological context. Furthermore, it has interesting characteristics due to its redox properties like its ability to undergo Fenton chemistry, which makes intracellular ROS production possible. Ruthenocene is very similar to ferrocene regarding its structure, lipophilicity and size, but it is more stable and not redox active, hence unable to induce Fenton chemistry. There is a wide variety of ferrocene conjugates known, but much less attention has been directed to the investigation of ruthenocene bioconjugates. In a pioneering study, our group recently presented the synthesis of a ruthenocene PNA oligomer and peptide conjugates. ${ }^{31-35}$

For the investigation of metallocene-polyarginine bioconjugates as candidates for LMP, we functionalize the peptide with ferrocene $(2,5$, Fig. 1$)$ or ruthenocene $(3,6)$. Furthermore, the compounds were labeled with the fluorophore FITC $(\mathbf{5}, \mathbf{6})$ to investigate their intracellular biological properties in terms of cytotoxicity and lysosomal localization. We have chosen a polyarginine peptide based on an optimized sequence by Iversen et al. which contains two phenylalanines in addition to the arginine core sequence for an improved interaction with the cell membrane. ${ }^{36}$ As a bonus, these two phenylalanine residues facilitate detection during HPLC purification due to their absorption in the UV.

\section{Experimental section}

\section{General experimental conditions}

All reagents and HPLC-grade solvents were purchased from Acros (Geel, Belgium), Aldrich/Sigma/Fluka (Deisenhofen, Germany), E. Merck (Darmstadt, Germany), Novabiochem (Laufelfingen, Switzerland) and IRIS Biotech (Marktredwitz, Germany) and were used without further purification. The Rink Amide linker (IRIS Biotech) and only L-amino acids were used

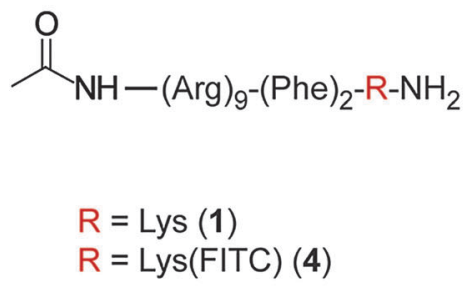

Fig. 1 Conjugates 1-6

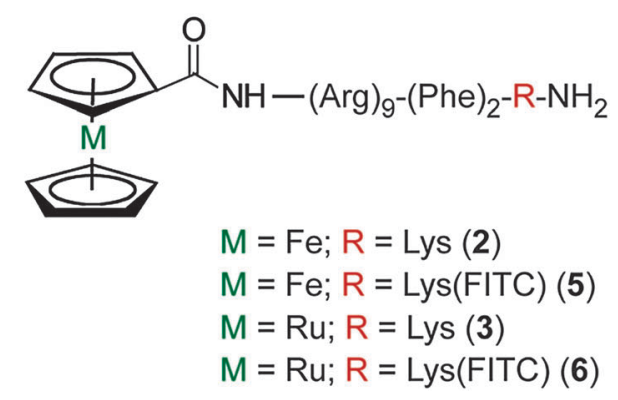


throughout the synthesis. FITC was ordered from Fluka Chemicals, DMF from Roth. All materials for cell culture were purchased from Invitrogen Corporation (Karlsruhe, Germany) unless otherwise specified. HPLC fractions of all products were frozen in liquid nitrogen and lyophilized using a Christ Alpha 1-4 LD plus freeze dryer. All aqueous solutions were prepared from Millipore ${ }^{\circledR}$ water and filtered with a $0.22 \mu \mathrm{m}$ syringe filter before use.

\section{Instrumentation and analytical measurements}

A Liberty Microwave Peptide Synthesizer from CEM was used for peptide synthesis. MALDI-TOF mass spectra were recorded on 'Daltonics ${ }^{\circledR}$ Autoflex' or Ultraflex III instruments (Bruker, Bremerhaven, Germany) in linear mode with positive polarity using sinapinic acid as the matrix. ESI mass spectra were recorded on an Esquire 6000 instrument (Bruker, Bremerhaven, Germany). Nuclear magnetic resonance spectra were recorded on a Bruker DRX $600 \mathrm{MHz}$ spectrometer (Bruker, Karlsruhe, Germany). ${ }^{1} \mathrm{H}$ and ${ }^{13} \mathrm{C}$ chemical shifts are given in $\mathrm{ppm}$ and were referenced with the residual solvent resonances relative to tetramethylsilane (TMS). Absorption was measured with a Tecan Microplate Platereader Saphire ${ }^{2}$ (Tecan, Crailsheim, Germany). Uptake studies were implemented on the Olympus IX51 fluorescence microscope equipped with an Olympus XC10 camera and localization studies were performed on a Leica DMIRE2 confocal microscope containing a Leica TCS SP2 and Leica CTRMIC.

\section{HPLC analysis and purification}

HPLC analysis and purifications were carried out using C18 analytical (Varian Dynamax, $4.6 \mathrm{~mm} \times 250 \mathrm{~mm}$ ) and C18 semipreparative (Varian Dynamax, $21.4 \mathrm{~mm} \times 250 \mathrm{~mm}$ ) columns on a customised Varian Prostar instrument. Linear gradient, 5-95\% MeCN in 18 min, eluents: $\mathrm{H}_{2} \mathrm{O}$ and MeCN both containing $0.1 \%(\mathrm{v} / \mathrm{v})$ TFA. Analytical (flow rate: $1.0 \mathrm{~mL} \mathrm{~min}^{-1}$ ) and preparative (flow rate: $4.0 \mathrm{~mL} \mathrm{~min}^{-1}$ ) runs were performed with a linear gradient of A (95\% millipore ${ }^{\circledR}$ water, $5 \% \mathrm{MeCN}$, $0.1 \%$ TFA (v/v/v)) and B (5\% millipore ${ }^{\circledR}$ water, 95\% MeCN, 0.1\% TFA (v/v/v)). Analytical runs: $t=0 \mathrm{~min}: 0 \% \mathrm{~B} ; t=18 \mathrm{~min}: 100 \%$ $\mathrm{B} ; t=26 \mathrm{~min}: 0 \% \mathrm{~B} ; t=30 \mathrm{~min}: 0 \% \mathrm{~B}$. Preparative runs: $t=0 \min : 0 \% \mathrm{~B} ; t=45 \mathrm{~min}: 50 \% \mathrm{~B} ; t=55 \mathrm{~min}: 100 \% \mathrm{~B}$; $t=65 \mathrm{~min}: 0 \% \mathrm{~B}$. All samples were filtered before injection using a $0.22 \mu \mathrm{m}$ syringe filter. Spectra were recorded at $254 \mathrm{~nm}$ and ambient temperature, retention times $\left(t_{\mathrm{R}} /[\mathrm{min}]\right)$ were noted in each case.

\section{Solid-phase peptide synthesis}

The resin bound Fmoc-polyarginine was synthesized on an automated peptide synthesizer using standard protocols (amino acid coupling: TBTU in DMF (0.5 M), HOBt in DMF (0.5 M), DIPEA in NMP (2 M) and amino acids in DMF (0.2 M); arginine coupling: $25 \mathrm{~min}, 75^{\circ} \mathrm{C}, 0 \mathrm{~W}$ followed by $5 \mathrm{~min}, 75^{\circ} \mathrm{C}$, $25 \mathrm{~W}$; standard amino acid coupling: $5 \mathrm{~min}, 75{ }^{\circ} \mathrm{C}, 24 \mathrm{~W}$. For deprotection: $20 \%$ piperidine in DMF: initial deprotection: $0.5 \mathrm{~min}, 75{ }^{\circ} \mathrm{C}, 30 \mathrm{~W}$ followed by deprotection: $3 \mathrm{~min}, 75{ }^{\circ} \mathrm{C}$, $50 \mathrm{~W}$ ). Afterwards, aliquots of $100 \mathrm{mg}$ peptide containing resin was transferred into a filter-containing syringe for further derivatization. For the synthesis of all compounds, the $\mathrm{N}$-terminal Fmoc group was deprotected and either acetylated $(\mathbf{1}, \mathbf{4})$ or coupled with ferrocenecarboxylic acid $(2,5)$ or ruthenocenecarboxylic acid $(3,6)$. After each step the resin was washed 5 times using $2 \mathrm{~mL}$ DMF.

Deprotection of Fmoc. The deprotection was performed twice by treating the Fmoc protected peptide with $2 \mathrm{~mL}$ of $20 \%$ piperidine in DMF ( 1 and $5 \mathrm{~min}$ ).

Acetylation. The N-terminus was acetylated after Fmoc deprotection using 5\% acetic anhydride and 6\% $\mathrm{N}, \mathrm{N}$-diisopropylethylamine (DIPEA) in DMF for $5 \mathrm{~min}$. This step was repeated five times.

Metallocene coupling. After Fmoc-deprotection, metallocenes were coupled to the free $\mathrm{N}$-terminus using metallocene carboxylic acid, 1-hydroxybenzotriazole (HOBt), 2-(1H-benzotriazole1-yl)-1,1,3,3-tetramethyluronium-tetrafluoroborate (TBTU), DIPEA, ( $4: 4: 4: 6$ equiv.) in DMF for $1 \mathrm{~h}$ or $3 \mathrm{~h}$ for the coupling of ferroceneor ruthenocenecarboxylic acid, respectively.

FITC coupling. To label the bioconjugates with the fluorophore FITC the Mtt-protecting group of the additional lysine was cleaved orthogonally $1 \%(\mathrm{v} / \mathrm{v})$ TFA, $5 \%(\mathrm{v} / \mathrm{v})$ TIS in DCM after N-terminus functionalization; The resin was treated with this cleavage mixture $(2 \mathrm{~mL})$ for $5 \mathrm{~min}$, this step was repeated five times. Afterwards, FITC was coupled to the side chain (4 eq. FITC, 10 eq. DIPEA in DMF, incubation time $10 \mathrm{~h}$ ) to result in $\mathbf{4}$, 5 and 6. After each step the resin was washed 5 times with $2 \mathrm{~mL}$ DMF.

Cleavage. The resin was washed with DMF and DCM, shrunk with $\mathrm{MeOH}$ and dried under vacuum for $30 \mathrm{~min}$. Finally, cleavage of the bioconjugate from the resin was performed using TFA/water/triisopropylsilane (TIS) (2 mL, $95: 2.5: 2.5)$ or TFA/phenol/TIS ( $2 \mathrm{~mL}, 85: 10: 5)$ for $6 \mathrm{~h}$ at room temperature. The resin was filtered and washed with $0.5 \mathrm{~mL}$ TFA. Addition of cold diethyl ether yielded a precipitate, which was washed repeatedly with diethyl ether. The crude product was dissolved in MeCN-water, filtered, lyophilized and afterwards purified and analyzed with RP-HPLC and finally characterized with MALDI-TOF mass spectrometry.

1: white solid, $\mathrm{C}_{80} \mathrm{H}_{143} \mathrm{~N}_{41} \mathrm{O}_{13}\left(1887.26 \mathrm{~g} \mathrm{~mol}^{-1}\right)$ : MS (MALDITOF): $m / z 1888.0[\mathrm{M}+\mathrm{H}]^{+}, 1910.0[\mathrm{M}+\mathrm{Na}]^{+}$, HPLC: $t_{\mathrm{R}}=10.5 \mathrm{~min}$. ${ }^{1} \mathrm{H}$ NMR (90\% $\left.\mathrm{H}_{2} \mathrm{O}: 10 \% \mathrm{D}_{2} \mathrm{O}, 600.13 \mathrm{MHz}\right): \delta=8.49-8.42(\mathrm{~m}, 6 \mathrm{H}$, $\mathrm{H}_{\mathrm{NH}, \mathrm{Arg}}$ ), 8.37-8.33 (m, 4H, $\left.\mathrm{H}_{\mathrm{NH}, \mathrm{Arg}}\right), 8.33$ (m, 1H, $\left.\mathrm{H}_{\mathrm{NH}, \mathrm{Phe} 1}\right), 8.23$ (m, 1H, $\mathrm{H}_{\mathrm{NH}, \mathrm{Lys}}$ ), 8.21 (m, 1H, $\mathrm{H}_{\mathrm{NH}, \mathrm{Phe} 2}$ ), 7.57 (br, 3H, $\mathrm{H}_{\zeta, \mathrm{Lys}}$ ), 7.39 (m, 2H, $\left.\mathrm{H}_{\text {phenyl,PheA }}\right), 7.38$ (m, 2H, $\left.\mathrm{H}_{\text {phenyl,PheB }}\right), 7.35(\mathrm{~m}, 2 \mathrm{H}$, $\left.1 \mathrm{H}_{\text {phenyl,PheA }}, \quad 1 \mathrm{H}_{\text {phenyl,PheB }}\right), 7.28$ (m, 2H, $\left.\mathrm{H}_{\text {phenyl,PheA }}\right), 7.27$ ( $\mathrm{m}, 2 \mathrm{H}, \mathrm{H}_{\text {phenyl,PheB }}$ ), 6.71 (br, 36H, $\mathrm{H}_{\eta, \mathrm{Arg}}$ ), 4.65 (m, 1H, $\mathrm{H}_{\alpha, \text { Phe1 }}$ ),

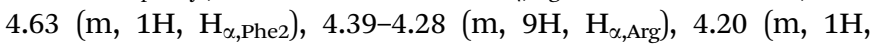
$\left.\mathrm{H}_{\alpha, \mathrm{Lys}}\right), 3.29-3.14\left(\mathrm{~m}, 18 \mathrm{H}, \mathrm{H}_{\delta, \mathrm{Arg}}\right), 3.11$ (m, $\left.1 \mathrm{H}, \mathrm{H}_{\beta 2, \text { Phe } 1}\right), 3.10$ (m, $\left.1 \mathrm{H}, \mathrm{H}_{\beta 2, \mathrm{Phe} 2}\right), 3.06$ (m, 1H, $\left.\mathrm{H}_{\varepsilon 2, \mathrm{Lys}}\right), 3.04$ (m, 1H, $\left.\mathrm{H}_{\varepsilon 3, \mathrm{Lys}}\right), 3.03$ (m, 1H, $\left.\mathrm{H}_{\beta 3, \text { Phe } 1}\right), 3.01$ (m, 1H, $\left.\mathrm{H}_{\beta 3, \text { Phe } 2}\right), 2.10$ (s, 3H, $\left.\mathrm{H}_{\text {Acetyl }}\right), 1.90-$ 1.84 (m, 9H, H $\left.\mathrm{H}_{\beta 2, \mathrm{Arg}}\right), 1.89-1.45$ (m, 18H, $\left.\mathrm{H}_{\gamma, \mathrm{Arg}}\right), 1.83-1.75$ (m, 9H, $\mathrm{H}_{\beta 3, \mathrm{Arg}}$ ), $1.82\left(\mathrm{~m}, 1 \mathrm{H}, \mathrm{H}_{\beta 2, \mathrm{Lys}}\right), 1.74\left(\mathrm{~m}, 1 \mathrm{H}, \mathrm{H}_{\gamma 2, \mathrm{Lys}}\right), 1.72(\mathrm{~m}, 1 \mathrm{H}$, $\left.\mathrm{H}_{\beta 3, \mathrm{Lys}}\right), 1.71$ (m, 1H, $\mathrm{H}_{\gamma 3 \text {,Lys }}$ ), 1.43 (m, 1H, $\mathrm{H}_{\gamma 2, \mathrm{Lys}}$ ), 1.40 (m, 1H, $\left.\mathrm{H}_{\gamma 3, \mathrm{Lys}}\right) .{ }^{13} \mathrm{C} \mathrm{NMR}\left(90 \% \mathrm{H}_{2} \mathrm{O}: 10 \% \mathrm{D}_{2} \mathrm{O}, 150.92 \mathrm{MHz}\right): \delta=182.6$, $175.9(\mathrm{CON}), 174.6(\mathrm{CON}), 174.3(\mathrm{CON}), 173.6(\mathrm{CON}), 173.5(\mathrm{CON})$, $173.4(\mathrm{CON}), 173.3(\mathrm{CON}), 173.1(\mathrm{CON}), 172.7$ (CON), $172.2(\mathrm{CON})$, 
172.1 (CON), 136.2, 136.1 ( $\mathrm{C}_{\gamma \text { Phe1,Phe2 }}$ ), 129.3, 129.2, 128.8, 128.7 $\left(\mathrm{C}_{\delta \text {,Phe1 }}, \mathrm{C}_{\delta \text {,Phe2 }}, \mathrm{C}_{\varepsilon, \text { Phe1 }}, \mathrm{C}_{\varepsilon, \text { Phe } 2}\right), 127.2,127.1\left(\mathrm{C}_{\zeta}\right.$, Phe1, $\left.\mathrm{C}_{\zeta, \text { Phe } 2}\right), 54.8$ $\left(\mathrm{C}_{\alpha, \text { Phe1 }}, \mathrm{C}_{\alpha, \text { Phe } 2}\right)$, 54.6-53.1 ( $\left.\mathrm{C}_{\alpha, \mathrm{Arg}}\right), 53.5\left(\mathrm{C}_{\alpha, \mathrm{Lys}}\right), 40.9-40.7\left(\mathrm{C}_{\delta, \mathrm{Arg}}\right)$, $39.5\left(\mathrm{C}_{\varepsilon, \text { Lys }}\right), 37.5\left(\mathrm{C}_{\beta, \text { PheA }}, \mathrm{C}_{\beta, \text { PheB }}\right), 30.5\left(\mathrm{C}_{\beta, \text { Lys }}\right), 28.5-27.6\left(\mathrm{C}_{\beta, \text { Arg }}\right)$, 26.6 ( $\left.\mathrm{C}_{\delta, \text { Lys }}\right), 24.9-24.1\left(\mathrm{C}_{\gamma, \mathrm{Arg}}\right), 22.1$ ( $\left.\mathrm{C}_{\gamma, \mathrm{Lys}}\right)$.

2: orange solid, $\mathrm{C}_{89} \mathrm{H}_{149} \mathrm{FeN}_{41} \mathrm{O}_{13}\left(2056.16 \mathrm{~g} \mathrm{~mol}^{-1}\right)$ : MS (ESI, pos.): $m / z 1029.4[\mathrm{M}+2 \mathrm{H}]^{2+}, 686.8[\mathrm{M}+3 \mathrm{H}]^{3+}, 515.6[\mathrm{M}+4 \mathrm{H}]^{4+}$, 412.9 $[\mathrm{M}+5 \mathrm{H}]^{5+}, 344.4[\mathrm{M}+6 \mathrm{H}]^{6+}$, HPLC: $t_{\mathrm{R}}=11.4 \mathrm{~min}$. ${ }^{1} \mathrm{H}$ NMR (DMSO- $\left.d_{6}, 600.13 \mathrm{MHz}\right): \delta=8.32(\mathrm{~d}, J=7.1 \mathrm{~Hz}, 1 \mathrm{H}$, $\left.\mathrm{H}_{\mathrm{NH}, \mathrm{Phe} 1}\right), 8.07\left(\mathrm{~m}, 7 \mathrm{H}, 1 \mathrm{H}_{\mathrm{NH}, \mathrm{Lys}}, 6 \mathrm{H}_{\mathrm{NH}, \mathrm{Arg}}\right), 8.02(\mathrm{~m}, 2 \mathrm{H}$, $\left.1 \mathrm{H}_{\mathrm{NH}, \mathrm{Arg}}, 1 \mathrm{H}_{\mathrm{NH}, \mathrm{Phe} 2}\right), 7.97\left(\mathrm{~d}, J=7.5 \mathrm{~Hz}, 1 \mathrm{H}, \mathrm{H}_{\mathrm{NH}, \mathrm{Arg}}\right), 7.92$ $\left(\mathrm{d}, J=7.7 \mathrm{~Hz}, 1 \mathrm{H}, \mathrm{H}_{\mathrm{NH}, \mathrm{Arg}}\right), 7.80-7.60\left(\mathrm{~m}, 12 \mathrm{H}, 9 \mathrm{H}_{\varepsilon, \mathrm{Arg}}, 3 \mathrm{H}_{\zeta, \mathrm{Lys}}\right)$, 7.60-6.80 (m, 46H, 36H $\left.\mathrm{H}_{\mathrm{Cp} 2}\right), 4.87$ (m, 1H, $\left.\mathrm{H}_{\mathrm{Cp} 5}\right), 4.57\left(\mathrm{~m}, 2 \mathrm{H}, 1 \mathrm{H}_{\alpha, \text { Phe1 }}, 1 \mathrm{H}_{\alpha, \text { Phe } 2}\right), 4.42$ $\left(\mathrm{m}, 2 \mathrm{H}, \mathrm{H}_{\mathrm{Cp} 3,4}\right)$, 4.41-4.17 (m, 9H, $\left.\mathrm{H}_{\alpha},{ }_{\mathrm{Arg}}\right), 4.23\left(\mathrm{~s}, 5 \mathrm{H}, \mathrm{H}_{\mathrm{Cp}^{\prime}}\right)$, $4.20\left(\mathrm{~m}, 1 \mathrm{H}, \mathrm{H}_{\alpha, \mathrm{Lys}}\right), 3.22-3.00\left(\mathrm{~m}, 18 \mathrm{H}, \mathrm{H}_{\delta, \mathrm{Arg}}\right), 3.08(\mathrm{~m}, 1 \mathrm{H}$,

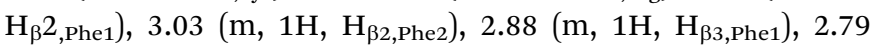
( $\left.\mathrm{m}, 2 \mathrm{H}, \mathrm{H}_{\varepsilon, \text { Lys }}\right), 2.77$ ( $\left.\mathrm{m}, 1 \mathrm{H}, \mathrm{H}_{\beta 3, \mathrm{Phe} 2}\right), 1.84-1.62\left(\mathrm{~m}, 9 \mathrm{H}, \mathrm{H}_{\beta 2, \mathrm{Arg}}\right)$, 1.71 (m, 1H, $\mathrm{H}_{\beta 2, \mathrm{Lys}}$ ), 1.62-1.40 (m, 9H, $\left.\mathrm{H}_{\beta 3, \mathrm{Arg}}\right), 1.57(\mathrm{~m}, 2 \mathrm{H}$, $\mathrm{H}_{\delta, \text { Lys }}$ ), $1.56\left(\mathrm{~m}, 1 \mathrm{H}, \mathrm{H}_{\beta 3, \text { Lys }}\right.$ ), $1.33\left(\mathrm{~m}, 2 \mathrm{H}, \mathrm{H}_{\gamma, \text { Lys }}\right) .{ }^{13} \mathrm{C}$ NMR (DMSO- $\left.d_{6}, 150.92 \mathrm{MHz}\right): \delta=174.1(\mathrm{CON}), 173.0(\mathrm{CON}), 172.3$ $(\mathrm{CON}), 172.0(\mathrm{CON}), 171.8(\mathrm{CON}), 171.6(\mathrm{CON}), 171.0(\mathrm{CON})$, 170.7 (CON), 130.1, 130.0, 129.0, $128.8\left(\mathrm{C}_{\delta, \text { Phe1 }}, \mathrm{C}_{\delta, \text { Phe } 2}, \mathrm{C}_{\zeta, \text { Phe } 1}\right.$, $\left.\mathrm{C}_{\zeta, \text { Phe } 2}\right), 127.2,121.4\left(\mathrm{C}_{\varepsilon, \text { Phe } 1}, \mathrm{C}_{\varepsilon, \text { Phe } 2}\right), 70.8\left(\mathrm{C}_{\mathrm{Cp} 3,4}\right), 69.9\left(\mathrm{C}_{\mathrm{Cp}^{\prime}}\right)$, $69.8\left(\mathrm{C}_{\mathrm{Cp} 2,5}\right), 54.4\left(\mathrm{C}_{\alpha, \text { Phe1,Phe } 2}\right), 53.6-52.7\left(\mathrm{C}_{\alpha, \mathrm{Arg}}\right), 52.9\left(\mathrm{C}_{\alpha, \mathrm{Lys}}\right)$, $41.1\left(\mathrm{C}_{\delta, \text { Arg }}\right), 39.3\left(\mathrm{C}_{\varepsilon, \text { Lys }}\right), 38.3\left(\mathrm{C}_{\beta, \text { Phe } 2}\right), 38.1\left(\mathrm{C}_{\beta, \text { Phe } 1}\right), 32.2$ $\left(\mathrm{C}_{\beta, \text { Lys }}\right), 29.8$ ( $\left.\mathrm{C}_{\beta, \mathrm{Arg}}\right), 27.4\left(\mathrm{C}_{\delta, \text { Lys }}\right), 25.6\left(\mathrm{C}_{\gamma, \mathrm{Arg}}\right), 22.8\left(\mathrm{C}_{\gamma, \text { Lys }}\right)$.

3: white solid, $\mathrm{C}_{89} \mathrm{H}_{149} \mathrm{~N}_{41} \mathrm{O}_{13} \mathrm{Ru}\left(2102.0 \mathrm{~g} \mathrm{~mol}^{-1}\right)$ : $\mathrm{MS}$ (MALDI-TOF, Sinap.): $m / z 2103.1[\mathrm{M}+\mathrm{H}]^{+}$, HPLC: $t_{\mathrm{R}}=12.8$ min. ${ }^{1} \mathrm{H}$ NMR (DMSO- $\left.d_{6}, 400.13 \mathrm{MHz}\right): \delta=8.27$ (d, $J=7.5 \mathrm{~Hz}$, $\left.1 \mathrm{H}, \mathrm{H}_{\mathrm{NH}, \mathrm{Phe} 1}\right), 8.16-8.11\left(\mathrm{~m}, 2 \mathrm{H}, \mathrm{H}_{\mathrm{NH}, \mathrm{Arg}}\right), 8.06$ (d, $J=7.8 \mathrm{~Hz}, 1 \mathrm{H}$, $\left.\mathrm{H}_{\mathrm{NH}, \mathrm{Lys}}\right), 8.00-7.90\left(\mathrm{~m}, 3 \mathrm{H}, \mathrm{H}_{\mathrm{NH}, \mathrm{Arg}}\right), 7.98(\mathrm{~d}, J=7.1 \mathrm{~Hz}, 1 \mathrm{H}$, $\left.\mathrm{H}_{\mathrm{NH}, \mathrm{Phe} 2}\right)$, 7.88-7.72 (m, $\left.4 \mathrm{H}, \mathrm{H}_{\mathrm{NH}, \mathrm{Arg}}\right)$, 7.85-7.72 $(\mathrm{m}, 12 \mathrm{H}$, $\left.9 \mathrm{H}_{\varepsilon, \mathrm{Arg}}, 3 \mathrm{H}_{\zeta, \mathrm{Lys}}\right), 7.55-7.02\left(\mathrm{~m}, 46 \mathrm{H}, 36 \mathrm{H}_{\eta \mathrm{Arg}}, 4 \mathrm{H}_{\delta, \mathrm{Phe}}, 4 \mathrm{H}_{\varepsilon, \mathrm{Phe}}\right.$, $\left.2 \mathrm{H}_{\zeta, \mathrm{Phe}}\right), 5.23\left(\mathrm{~m}, 1 \mathrm{H}, \mathrm{H}_{\mathrm{Cp} 2}\right), 5.20\left(\mathrm{~m}, 1 \mathrm{H}, \mathrm{H}_{\mathrm{Cp} 5}\right), 4.70(\mathrm{~m}, 2 \mathrm{H}$, $\left.\mathrm{H}_{\mathrm{Cp} 3,4}\right), 4.58\left(\mathrm{~s}, 5 \mathrm{H}, \mathrm{H}_{\mathrm{Cp}^{\prime}}\right), 4.52\left(\mathrm{~m}, 1 \mathrm{H}, \mathrm{H}_{\alpha}, \mathrm{Phe} 1\right), 4.50(\mathrm{~m}, 1 \mathrm{H}$, $\mathrm{H}_{\alpha, \text { Phe } 2}$ ), 4.33-4.14 (m, 9H, $\mathrm{H}_{\alpha}$, Arg $), 4.16$ (m, 1H, $\left.\mathrm{H}_{\alpha, \mathrm{Lys}}\right), 3.15-$ $2.69\left(\mathrm{~m}, 18 \mathrm{H}, \mathrm{H}_{\delta, \mathrm{Arg}}\right), 3.04\left(\mathrm{~m}, 1 \mathrm{H}, \mathrm{H}_{\beta 2, \mathrm{Phe} 1}\right), 2.98(\mathrm{~m}, 1 \mathrm{H}$, $\left.\mathrm{H}_{\beta 2 \text {,Phe } 2}\right), 2.84\left(\mathrm{~m}, 1 \mathrm{H}, \mathrm{H}_{\beta 3 \text {,Phe } 1}\right), 2.75\left(\mathrm{~m}, 2 \mathrm{H}, \mathrm{H}_{\varepsilon, \text { Lys }}\right), 2.72$ (m, 1H, $\left.\mathrm{H}_{\beta 3, \mathrm{Phe} 2}\right)$, 1.69-1.58 (m, 18H, $\left.\mathrm{H}_{\beta, \mathrm{Arg}}\right), 1.67(\mathrm{~m}, 2 \mathrm{H}$, $\mathrm{H}_{\beta, \text { Lys }}$ ), 1.57-1.33 (m, 18H, $\mathrm{H}_{\gamma, \text { Arg }}$ ), $1.52\left(\mathrm{~m}, 2 \mathrm{H}, \mathrm{H}_{\delta, \text { Lys }}\right), 1.29$ $\left(\mathrm{m}, 2 \mathrm{H}, \mathrm{H}_{\gamma, \text { Lys }}\right) .{ }^{13} \mathrm{C}$ NMR (DMSO- $\left.d_{6}, 100.61 \mathrm{MHz}\right): \delta=173.3$ $(\mathrm{CON}), 171.8(\mathrm{CON}), 171.7(\mathrm{CON}), 171.5(\mathrm{CON}), 171.4(\mathrm{CON})$, $171.3(\mathrm{CON}), 171.1(\mathrm{CON}), 170.9(\mathrm{CON}), 170.7(\mathrm{CON}), 168.5$ (CON), 137.6, 137.5 ( $\left.\mathrm{C}_{\gamma, \text { Phe1 }}, \mathrm{C}_{\gamma, \text { Phe } 2}\right), 129.3,128.8,128.1,128.0$, 123.1, $120.6\left(\mathrm{C}_{\delta \text {,Phe1 }}, \mathrm{C}_{\delta \text {,Phe2 }}, \mathrm{C}_{\varepsilon, \text { Phe1 }}, \mathrm{C}_{\varepsilon, \text { Phe2 }}, \mathrm{C}_{\zeta, \text { Phe1 }}, \mathrm{C}_{\zeta, \text { Phe } 2}\right), 72.1$ $\left(\mathrm{C}_{\mathrm{Cp} 3,4}\right), 71.6\left(\mathrm{C}_{\mathrm{Cp}^{\prime}}\right), 70.5\left(\mathrm{C}_{\mathrm{Cp} 5}\right), 70.3\left(\mathrm{C}_{\mathrm{Cp} 2}\right)$, 54.1, $53.6\left(\mathrm{C}_{\alpha, \text { Phe1 }}\right.$, $\left.\mathrm{C}_{\alpha, \text { Phe } 2}\right)$, 52.6-51.9 ( $\left.\mathrm{C}_{\alpha, \text { Arg }}\right), 52.1$ ( $\left.\mathrm{C}_{\alpha, \text { Lys }}\right), 41.738 .7\left(\mathrm{C}_{\delta, \text { Arg }}\right), 38.4$ $\left(\mathrm{C}_{\varepsilon, \text { Lys }}\right), 37.6\left(\mathrm{C}_{\beta, \text { Phe } 2}\right), 37.5\left(\mathrm{C}_{\beta, \text { Phe } 1}\right), 31.4\left(\mathrm{C}_{\beta, \text { Lys }}\right), 31.3\left(\mathrm{C}_{\delta, \text { Lys }}\right)$, 29.4-28.3 ( $\left.\mathrm{C}_{\beta, \text { Arg }}\right), 25.3,25.0-24.8\left(\mathrm{C}_{\gamma, \mathrm{Arg}}\right), 22.0\left(\mathrm{C}_{\gamma, \mathrm{Lys}}\right)$.

4: yellow solid, $\mathrm{C}_{101} \mathrm{H}_{154} \mathrm{~N}_{42} \mathrm{O}_{18} \mathrm{~S}\left(2275.21 \mathrm{~g} \mathrm{~mol}^{-1}\right)$ : $\mathrm{MS}$ (MALDI-TOF, Sinap.): $m / z 2282.7[\mathrm{M}]^{+}$; MS (ESI, pos.): $m / z$ 1138.8 $[\mathrm{M}+2 \mathrm{H}]^{2+}, 944.4[\mathrm{M}-\mathrm{FITC}+3 \mathrm{H}]^{2+}, 759.6[\mathrm{M}+3 \mathrm{H}]^{3+}$, $629.9[\mathrm{M}-\text { FITC }+4 \mathrm{H}]^{3+}$, HPLC: $t_{\mathrm{R}}=13.1 \mathrm{~min}$.

5: yellow solid, $\mathrm{C}_{110} \mathrm{H}_{160} \mathrm{FeN}_{42} \mathrm{O}_{18} \mathrm{~S}\left(2445.20 \mathrm{~g} \mathrm{~mol}^{-1}\right)$ : $\mathrm{MS}$ (MALDI-TOF, Sinap.): $m / z 2447.1[\mathrm{M}+\mathrm{H}]^{+}$, MS (ESI, pos.): $m / z$
1223.8 $[\mathrm{M}+2 \mathrm{H}]^{2+}, 1029.4[\mathrm{M}-\text { FITC }+3 \mathrm{H}]^{2+}, 816.8[\mathrm{M}+4 \mathrm{H}]^{3+}$, $686.6[\mathrm{M}-\mathrm{FITC}+3 \mathrm{H}]^{3+}$, HPLC: $t_{\mathrm{R}}=14.8 \mathrm{~min}$.

6: yellow solid, $\mathrm{C}_{110} \mathrm{H}_{160} \mathrm{~N}_{42} \mathrm{O}_{18} \mathrm{RuS}$ (2491.17 $\mathrm{g} \mathrm{mol}^{-1}$ ): $\mathrm{MS}$ (ESI, pos.): $m / z 831.5[\mathrm{M}+3 \mathrm{H}]^{3+}, 701.7[\mathrm{M}-\mathrm{FITC}+4 \mathrm{H}]^{3+}, 390.0$ $[\text { FITC }+\mathrm{H}]^{+}$. HPLC: $t_{\mathrm{R}}=14.9 \mathrm{~min}$.

\section{Membrane studies}

A Quartz crystal microbalance (QCM) was used to assess the interaction between polyarginine peptides and a supported biomimetic membrane (SBM). This approach has been extensively explained in previous works. ${ }^{37,38}$ Briefly, QCM experiments were performed using the E4 system with flow cells (Q-Sense, Västra Frölunda, Sweden). The QCM instrument measures the relative changes to the resonance frequency $(\Delta f)$ of the sensor over the course of the experiment. The variation in the resonance frequency is proportional to the change of the mass $(\Delta m)$ coupled to the sensor surface by the Sauerbrey equation: ${ }^{37}$

$$
\Delta m=-C\left(\Delta f_{n} / n\right)
$$

where $C$ is the mass sensitivity constant $\left(17.7 \mathrm{ng} \mathrm{cm}^{-2} \mathrm{~Hz}\right.$ for a chip with a fundamental frequency of $5 \mathrm{MHz}$ ) and $n$ is the harmonic number. Each experiment was implemented, firstly by the creation of a SBM, by introducing liposomes consisting of dimyristoylphosphatidylcholine (DMPC), DMPC/cholesterol $(7: 3 \mathrm{v} / \mathrm{v})$ or DMPC/DMPG $(4: 1 \mathrm{v} / \mathrm{v})$, suspended in a $20 \mathrm{mM}$ PBS buffer with $100 \mathrm{mM}$ of $\mathrm{NaCl}$, into the QCM chamber. The deposition occurred thus in situ, onto a gold sensor, which has been previously modified with a layer of 3-mercaptopropionic acid (MPA) or with 6-mercaptohexanoic acid (MHA). Once a stable bilayer (membrane) was formed, various concentrations of peptide, dissolved in PBS, were introduced. The interaction of the peptide and subsequent effects were recorded in real time at the various harmonics (3rd, 5th, 7th and 9th), simultaneously. However, only the 7th is represented in this study, since the other harmonics did not show any substantial difference. The last step of the experiment, after the incubation time for the peptidemembrane system, was a PBS flush with the purpose of removing any peptide molecule weakly bound to the membrane. All experiments were conducted at a temperature of $19.10 \pm 0.05{ }^{\circ} \mathrm{C}$.

\section{Cell culture}

General procedure. The human HepG2 cell line was obtained from "Deutsche Sammlung von Mikroorganismen und Zellkultur ACC 180”. The cell lines HeLa, IMIM-PC2 and PT45 were a gift of Prof. Heumann (Biochemistry, RuhrUniversity Bochum) and Prof. Hahn (Molecular Oncology, Ruhr-University Bochum, Bochum, Germany). Cells were grown in RPMI 1640 with 1\% sodium pyruvate, 1\% L-glutamine, 100 units per $\mathrm{mL}$ Pen Strep, $10 \%$ fetal bovine serum. The cells were maintained at $37{ }^{\circ} \mathrm{C}$ in a humidified incubator under an atmosphere containing $5 \% \mathrm{CO}_{2}$. Wells used for HeLa cells were coated with $0.2 \%$ gelatine solution before use.

\section{Cellular uptake}

The uptake was investigated by fluorescence microscopy using conjugates labeled with the fluorophore FITC (compounds 4 , 
5 and 6). $8 \times 10^{4}$ cells were seeded in flat bottom 24 well plates and incubated for $24 \mathrm{~h}$ at $37{ }^{\circ} \mathrm{C}$ and $5 \%$ (HepG2) or $10 \% \mathrm{CO}_{2}$ (IMIM-PC2, PT45). Due to an enhanced solubility of the compounds, $0.5 \%$ DMSO (maximal concentration in the cell medium) was added. The compounds were dissolved in a DMSO-PBS solution, added to the cell medium and incubated with the cells for $14 \mathrm{~h}$ using five different concentrations (1, 5, $10,25,50 \mu \mathrm{M})$. After completion of the incubation, the cell medium was removed and the cells were washed five times with PBS. The PBS was replaced with cell culture medium and the fluorescence of the cells was measured on a fluorescence microscope Olympus IX51 (magnification 100, 200 or 400 times). To assess the effect of the cellular uptake qualitatively the amount of fluorescent cells and the intensity of the fluorescence were compared visually.

\section{Colocalization}

Colocalization studies were performed using confocal microscopy. For colocalization, commercially available dyes were used according to the specifications of the manufacturer for live cell experiments. To visualize lysosomes LysoTracker Red ${ }^{\mathbb{R}}$ was used, for endosomes the FM 4-64 ${ }^{\circledR}$ dye was employed.

$2.5 \times 10^{4}$ cells were seeded in manually poly-L-lysine coated ibidi $\mu$-slides ( 8 wells) for $14 \mathrm{~h}$. The cells were incubated with $10 \mu \mathrm{M}$ of 5 for $2 \mathrm{~h}$. $30 \mathrm{~min}$ before the end of the incubation time LysoTracker Red $^{\circledR}(75 \mathrm{nM})$ or FM $4-64^{\circledR}(10 \mu \mathrm{M})$ were added. After completion of the incubation, the culture medium was removed and the cells were washed 5 times using PBS and replaced with RPMI 1640 medium without phenol red and supplements. The colocalization was measured on a Leica confocal microscope. Measurement parameters used for colocalization studies of $\mathbf{5}$ are as followed: excitation wavelength of $488 \mathrm{~nm}$ and emission range between $500-525 \mathrm{~nm}$, for LysoTraker $\operatorname{Red}^{\circledR}$ excitation wavelength of $543 \mathrm{~nm}$ and emission range of 590-620 nm, for FM 4-64 ${ }^{\mathbb{R}}$ excitation wavelength of $514 \mathrm{~nm}$ and emission range of 700-800 $\mathrm{nm}$. Pictures were recorded using the sequential imaging mode. To obtain one image, an average of at least three recorded images and an average of two recorded lines were used.

\section{Cytotoxicity experiments}

To determine the activity of 2 and 3 in comparison to 1, two antiproliferative assays, resazurin and crystal violet were performed (see ESI $\dagger$ for details). 6000 cells per well of HeLa, PT45 and HepG2 cells were incubated in 96-well plates at $37{ }^{\circ} \mathrm{C}$ and $10 \% \mathrm{CO}_{2}$ for $24 \mathrm{~h}$. To determine the initial cell viability and biomass, a $t_{0}$-plate with HeLa, HepG2 and PT45 was additionally plated and after $24 \mathrm{~h}$ incubation the resazurin assay was performed. Subsequently the cells were fixed with $0.2 \%$ glutardialdehyde solution, followed by the crystal violet assay. In the remaining plates the medium was replaced with medium containing 1, 2 or 3 with $0.5 \%$ DMSO added to improve the solubility of the compound. Concentrations between 1-1000 $\mu \mathrm{M}$ were used and later adapted regarding their antiproliferative activity. Each concentration was tested six times in parallel, as positive control, cisplatin was used and as negative control, medium containing $0.5 \%$ DMSO. To determine the effect of metallocenes, ferrocene- and ruthenocenecarboxylic acid were tested. The incubation time of the compounds was $48 \mathrm{~h}$. Then, the compound-containing medium was removed, the cells were washed with PBS and the resazurin assay and afterwards the crystal violet assay (see ESI $\dagger$ ) was performed. The mean absorption of the initial cell plate ( $t_{0}$-plate) for each cell line was subtracted from the absorption of each experiment and control. For both assays the negative control (non-treated) was set to $100 \%$.

\section{Apoptosis}

Annexin V/propidium iodide (AnnV/PI) staining. HeLa cells were treated with indicated concentrations of the substances for $48 \mathrm{~h}$, collected and stained with Annexin V-FITC conjugate (eBioscience) according to manufacturer's recommendation. Briefly, approximately $5 \times 10^{5}$ cells were resuspended in $50 \mu \mathrm{l}$ of Annexin V binding buffer, $2.5 \mu \mathrm{l}$ of Annexin V conjugate was added to each probe and $1.25 \mu$ l of PI solution $\left(1 \mathrm{mg} \mathrm{ml}^{-1}\right)$ and incubated in the dark at room temperature for 15 minutes. Signal intensity was analyzed using a FACS ${ }^{\circledR}$ Calibur (Becton Dickinson) and CellQuest Pro (BD) analysis software. Excitation and emission settings were $488 \mathrm{~nm}, 515-545 \mathrm{~nm}$ (FL1 channel) for Annexin V-FITC and 564-606 nm (FL2 channel) for PI.

\section{ROS measurements}

After the treatment of HeLa cells with indicated concentrations of the compound, the cells were collected, washed and re-suspended $\left(2.5 \times 10^{5}\right.$ cells per $\left.0.5 \mathrm{~mL}\right)$ in FACS buffer [D-PBS (Gibco) with 1\% BSA (PAA)]. $1.25 \mu \mathrm{l}$ of $5 \mathrm{mM}$ dihydroethidium (D1168, Molecular Probes, Invitrogen) solution was added to each sample followed by 15 minutes incubation at RT in the dark. Signal intensity in which represent the intracellular ROS level was analyzed using a FACS ${ }^{\mathbb{R}}$ Calibur (Becton Dickinson) and CellQuest Pro (BD) analysis software. Excitation and emission settings were $488 \mathrm{~nm}$ and 564-606 nm (FL2 channel).

\section{Cell cycle studies}

After $24 \mathrm{~h}$ treatment of $5 \times 10^{5} \mathrm{HeLa}$ cells with indicated concentrations of substances, cells were harvested and fixed with $70 \%$ ethanol. Fixed cells were kept at $-20{ }^{\circ} \mathrm{C}$ for at least one day and then washed with PBS and stained with propidium iodine for $30 \mathrm{~min}$ in the dark. Samples were then analyzed by FACS $^{\mathbb{R}}$ Calibur to determine the DNA content and cell cycle analysis.

\section{BIONAS real-time cell metabolism assay}

Approximately $2 \times 10^{5} \mathrm{HeLa}$ cells were seeded in $450 \mu \mathrm{l}$ medium in each biosensor chips (SC1000) $24 \mathrm{~h}$ prior insertion of the chips into the Bionas 2500 analyzer (Bionas, Rostock, Germany). The cell number used results in approximately $80 \%$ cell confluence on the chip surface after $24 \mathrm{~h}$. During the analysis of cell metabolism, cells were fed with DMEM running medium (PAN Cat. Nr. P03-0010) without sodium bicarbonate, and only buffered with $1 \mathrm{mM}$ Hepes, supplemented $0.1 \%$ FCS. A Bionas 2500 analyzing system was used to continuously 
record two important physiological cellular parameters over time: oxygen consumption, change in medium $\mathrm{pH}^{39}$ The metabolic sensor chips (SC1000) include ion-sensitive field effect transistors (ISFETs) to record $\mathrm{pH}$ changes which are linked with glycolytic activity of the cells, and Clark-type electrodes to monitor oxygen consumption representing mitochondrial activity. To measure the activity of the compounds we included the three following steps: (i) $6 \mathrm{~h}$ equilibration with running medium (RM). (ii) drug incubation with substances freshly dissolved in medium at the indicated concentrations for treatment periods of up to $24 \mathrm{~h}$, and (iii) a drug-free step in which cells are again fed with running medium only. At the end of each experiment, the cells were killed by addition of $0.2 \%$ Triton X-100 to get a basic signal without living cells on the sensor surface as a negative control.

\section{Results}

\section{Synthesis}

The peptides and peptide conjugates used in this study are shown in Fig. 1. For our purpose, we adapted the polyarginine sequence designed by Iversen et al. with minor changes. ${ }^{36}$ Instead of including a cysteine as part of the original sequence, we integrated a lysine to accommodate the fluorophore FITC.

The synthesis route of the bioconjugates reported in this article is shown in Scheme 1. The polyarginine peptide was prepared by solid-phase peptide synthesis (SPPS) using the
Fmoc technique. The complete peptide sequence ((Arg) $)_{9}$ (Phe $)_{2}$-Lys) was assembled on an automated, microwave assisted synthesizer. All subsequent steps were performed manually. After deprotection of the terminal Fmoc group the peptide was either acetylated $(\mathbf{1}, \mathbf{4})$, or ferrocenecarboxylic acid $(2,5)$ and ruthenocenecarboxylic acid $(3,6)$ were coupled to the $\mathrm{N}$-terminus of the sequence, respectively. In compounds $\mathbf{1}, 2$ and 3 the fluorophore is absent (see Fig. 1), with the sequence containing an unmodified lysine. The synthesis of compounds 4, 5 and 6 required an orthogonally cleavable protecting group to bind FITC after deprotection. To this end, we have chosen the rather acid labile Mtt group. The fluorophore labeling was achieved by removal of the Mtt group by 1\% TFA, followed by FITC coupling to the side chain of the unprotected lysine.

The conjugates were successfully cleaved from the resin after 6 hours by $85-95 \%$ TFA, which leaves the metallocene units untouched. All compounds were obtained successfully in a good yield and purity. The crude product of $\mathbf{1}$ and $\mathbf{3}$ were obtained with a purity of $>95 \%$.

The conjugates were purified by reverse-phase HPLC on a C18 column and found to be $>98 \%$ pure by subsequent analytical HPLC of all metallocene-containing fractions. The identity of the purified products was verified by mass spectrometry (ESI and MALDI-TOF). Furthermore, compounds 1, 2 and 3 were additionally characterized by $1 \mathrm{D}$ and $2 \mathrm{D}$ NMR spectroscopy.

HPLC chromatograms of the purified compounds reveal a short retention time of the bioconjugate due to the hydrophilicity

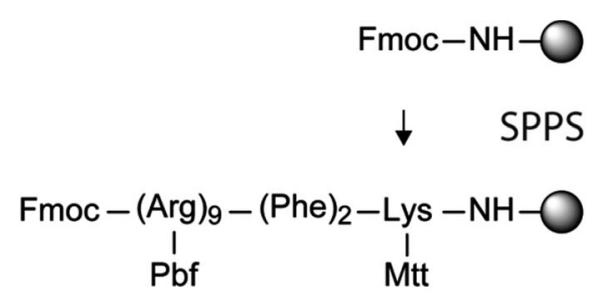

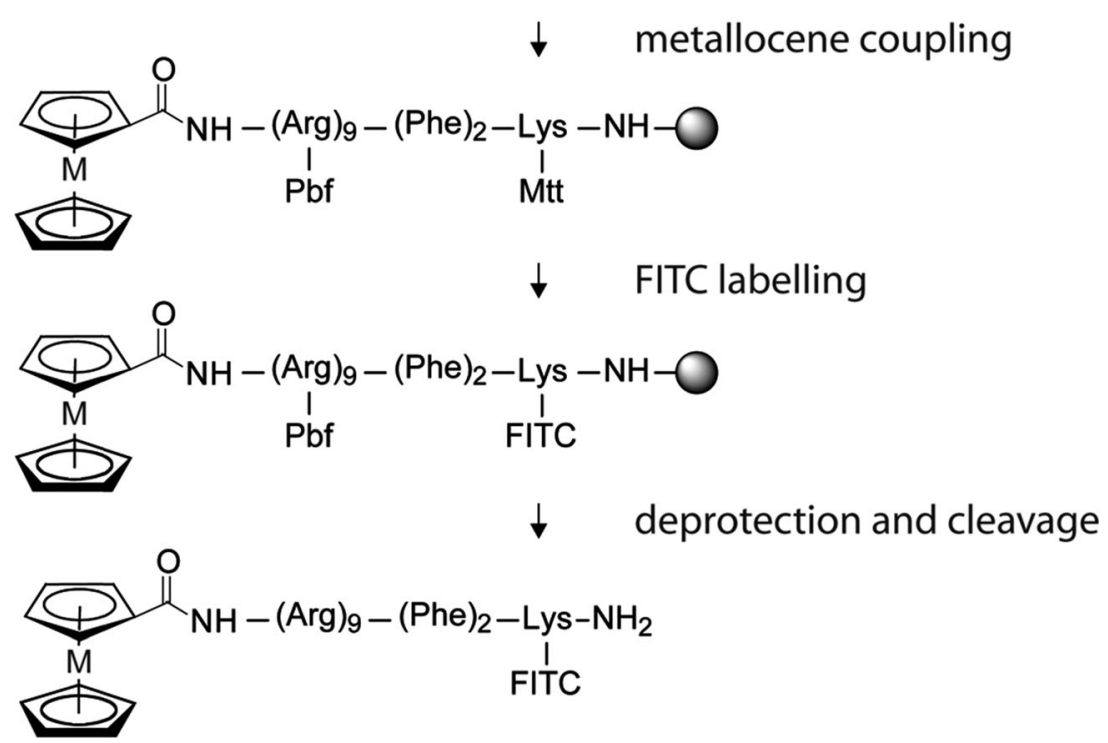

Scheme 1 Schematic preparation of FITC-labeled metallocene polyarginine conjugates; $M=F e(5), R u(6)$. 
of the peptide moiety. Coupling of ferrocene or ruthenocene to polyarginine results in a higher lipophilicity which was further increased by the FITC label $(\mathbf{5}, \mathbf{6})$. Ferrocene and ruthenocene conjugation show a longer but comparable retention time, due to the comparable lipophilicity of these metallocenes (see Experimental section and Fig. S1, ESI $\dagger$ ).

\section{Biological studies}

The biological properties were examined to evaluate the potential of metallocene polyarginine bioconjugates towards lysosomal destabilization and possible antiproliferative activity. Therefore, we studied their cytotoxicity, cellular uptake, localization and vesicular/membrane destabilization on live cells and on artificial membranes. To gain further insights into the mode of action, induction of apoptosis and necrosis, ROS formation, and their influence on the fluidity of a eukaryotic-mimic membrane were studied. Furthermore, the impact on cell cycle, cellular respiration and glycolysis were also investigated.

Peptide interaction with artificial membranes. To test the influence of the compounds towards a membrane, we investigated the effect of $\mathbf{1}, 2$ and 3 on an artificial eukaryotic membrane model. Fig. 2 illustrates the interaction between 1 (Fig. 2A) or 3 (Fig. 2B) peptide and a DMPC/cholesterol membrane $(3: 1 \mathrm{v} / \mathrm{v})$ (eukaryotic mimic). ${ }^{38,40}$

The QCM traces reveal, firstly, that peptides bind very strongly in a trans-membrane manner with no indication of membrane removal (see Fig. S2, ESI $\dagger$ ). Furthermore, the change in frequency is the same for both peptides $(\mathbf{1}, \mathbf{3})(\Delta f=-8 \mathrm{~Hz}$ for $5 \mu \mathrm{M})$. To notice also that this frequency change occurs for all the three concentrations tested, with a difference of $\pm 0.3 \mathrm{~Hz}$. Indeed, the peptides at these three concentrations nearly saturate the membrane, since the traces start to flatten when the peptide flow terminates (II). Similar behaviour was observed also for the peptide 2, which showed a similar uptake (see Fig. S3, ESI $\dagger$ ). However, these peptides acted as membranolytic peptides towards negatively charged membranes (DMPC/DMPG, $4: 1 \mathrm{v} / \mathrm{v}$ ), that mimic a bacterial cell membrane. ${ }^{38,41}$ Indeed, these peptides inserted into the membrane although this binding is immediately followed by removal of material (mass), presumably lipidrich molecules, which corresponds to an increase in frequency (see Fig. S4, ESI $\dagger$ ).

Cellular uptake. Cellular uptake of polyarginine and its conjugates was reported to happen in a receptor independent way and therefore, independent of the cell line. The proposed mechanism includes the uptake via binding of the positively charged arginine side chains to the cell membrane, in an electrostatic manner. ${ }^{23,24}$

Fluorophore labeled bioconjugates 4, 5 and 6 were tested on three cell lines, HepG2, IMIM-PC2 and PT45, revealing a good uptake in all three cell lines. The HepG2 cell line was previously found to give reliable and reproducible results in cell uptake studies of metallocene-peptide conjugates. ${ }^{28,42}$ The other two cell lines are derived from pancreatic cancers, which are more difficult to treat clinically and show a reduced uptake in general.

Incubation of cells with a high concentration of $50 \mu \mathrm{M}$ reveals a good cellular uptake into the tested cell lines (Fig. 3A). Interestingly, here the breakage of the vesicular structure was observed during exposure to the excitation light of the microscope at $488 \mathrm{~nm}$ (Fig. 3B).

Fig. S5 (see ESI $\dagger$ ) presents the results of the cellular uptake studies of PT45 at $10 \mu \mathrm{M}$, bearing in mind, that the uptake into the other two cell lines HepG2 and IMIM-PC2 is comparable (data not shown). Cellular uptake studies of the polyarginine bioconjugates 4, 5 and 6 revealed a good uptake in PT45 cells (Fig. S5, ESI $\dagger$ ) appearing in a vesicular perinuclear localization. By visual inspection, an incubation of $10 \mu \mathrm{M}$ of 4 results in a cellular uptake in around $50 \%$ of the cells. The amount of fluorescent cells increases with higher peptide concentration. Photo-induced breakage of the vesicular structure was observed for 4 by the microscope's excitation light after a relatively long exposure time of approximately $5 \mathrm{~min}$ (Fig. S5B, ESI $\dagger$ ), which could be impelled by a higher compound concentration, revealing a concentration dependent light-induced vesicular breakage for the fluorophore labeled polyarginine peptide.

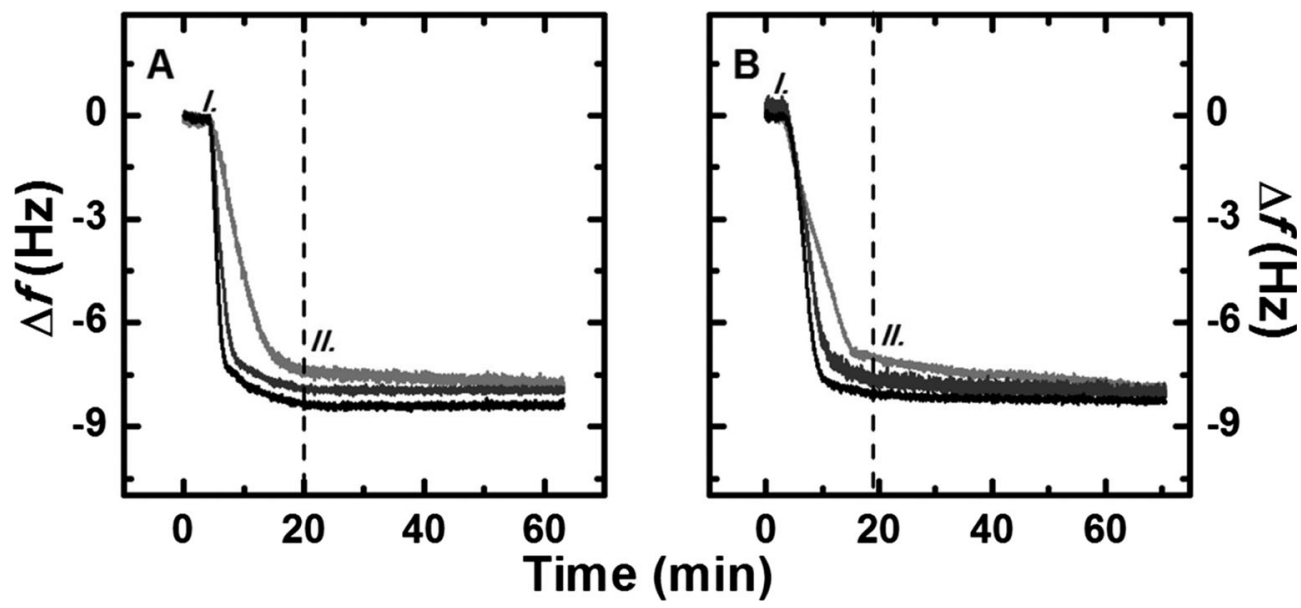

Fig. 2 Plots of frequency change vs. time ( $\Delta f-t$ plots) obtained for peptides 1 (A) and $\mathbf{3}$ (B) interacting with a DMPC-cholesterol membrane. The concentrations used are 1, 5 and $10 \mu \mathrm{M}$ (from the lightest to the darkest trace). The 7th harmonic only is shown. The vertical dash line indicates the time when the peptide flow stopped (II), while I. corresponds to the beginning of the peptide injection into the QCM chamber. 

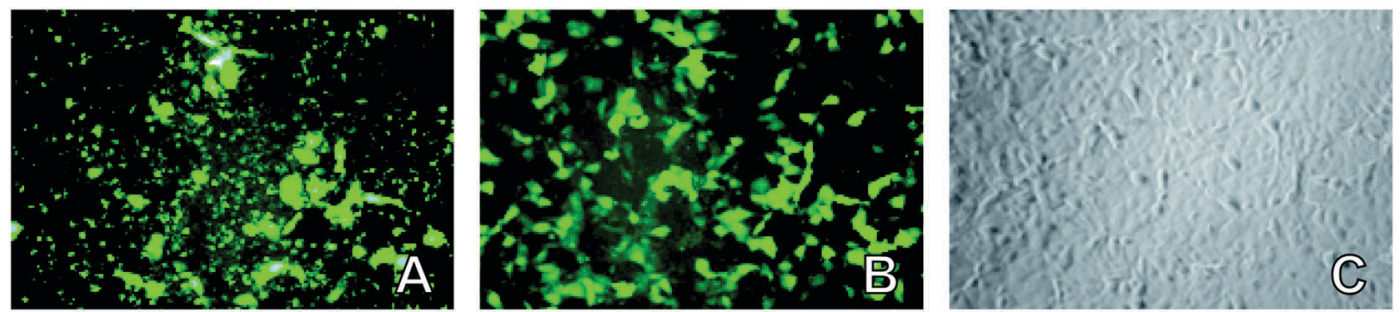

Fig. 3 Cellular uptake of $5(50 \mu \mathrm{M})$ in PT45 cells after $14 \mathrm{~h}$ incubation. (A) fluorescence image, $t=0$; (B) fluorescence image, $t=3$ min; (C) phase contrast. FITC-filter, $200 \times$ magnification.

Uptake studies of the metallocene peptides $\mathbf{5}$ and $\mathbf{6}$ show a stronger destabilization of the vesicles and an enhanced breakage (see Fig. 3 and Fig. S5D-I, ESI $\dagger$ ) in comparison to 4, which is in agreement with the observed higher uptake for both compounds. Furthermore, with a higher peptide concentration the exposure time could be dramatically reduced. Therefore, as seen in Fig. 3A the breakage of the vesicular structure starts immediately.

Incubation of the cells with a $10 \mu \mathrm{M}$ concentration of the metallocene bioconjugates 5 and $\mathbf{6}$ exhibit a significant uptake as seen by an intense fluorescence and photo induced breakage of vesicles in nearly all plated PT45 cells (Fig. S5D-I, ESI $\dagger$ ). They show a vesicular, perinuclear localisation comparable to $\mathbf{4}$, but additionally exhibit a low cytosolic localization, indicating a light independent leakage of compound out of the vesicles into the cytosol. However, metallocene peptides $\mathbf{5}$ and $\mathbf{6}$ reveal an enhance uptake compared to 4 . This is presented by an increased content of fluorescent cells exhibiting a higher intensity of the fluorescence and a quicker and more extensive light induced breakage of the vesicular structure, with a homogeneous distribution in the cytosol and a higher intensity in the nucleus. The efficiency of the cellular uptake increases in the order acetyl-polyarginine $(4)<$ ruthenocenoyl-polyarginine $(6)<$ ferrocenoyl-polyarginine (5).

Localization. The intracellular localization of $\mathbf{5}$ was studied in living cells by confocal microscopy. The previously presented uptake studies revealed a comparable vesicular distribution in the tested cells for all FITC-labelled compounds. In order to identify the cellular targets of these compounds, colocalization studies were performed in the human liver cancer cell line HepG2. By visual inspection, all metal-peptide conjugates exhibit the same intracellular distribution, and therefore, $\mathbf{5}$ was used as a model compound. The cells were co-incubated with vesicular compartment dyes LysoTracker Red ${ }^{\circledR}$ for visualizing lysosomes and FM $4-64{ }^{\circledR}$ for endosomes.

Colocalization of 5 results in a detained uptake of FM 4-64 ${ }^{\mathbb{R}}$ (Fig. 4A-C). Cells containing FM 4-64 ${ }^{\circledR}$ after the incubation reveal the release of 5 into the cell body indicating the chemically
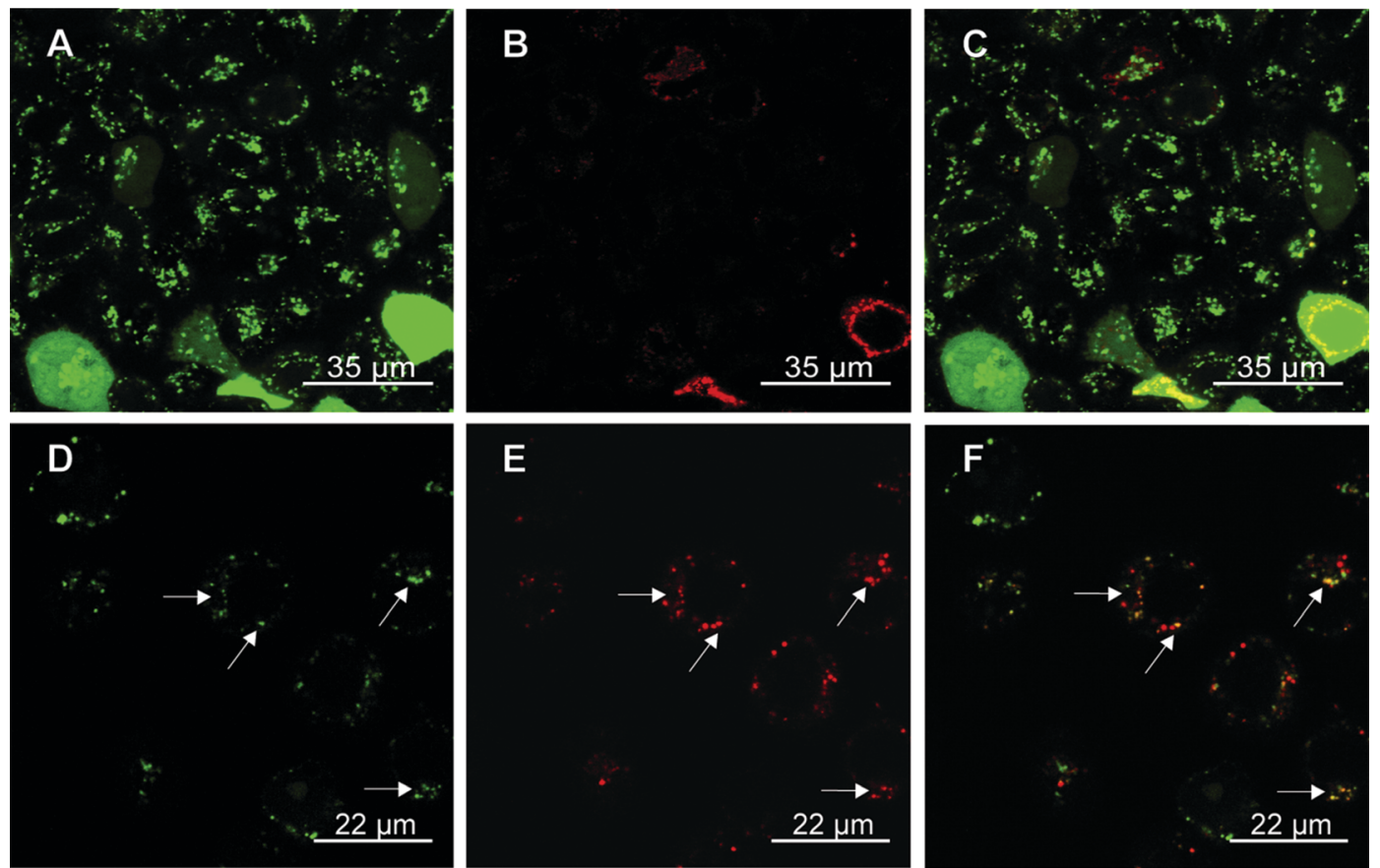

Fig. 4 Colocalization study in HepG2 cells; (A) $5(10 \mu \mathrm{M})$, (B) FM 4-64 ${ }^{\mathbb{R}}(10 \mu \mathrm{M})$, (C) overlay of A and B. (D) 5 (10 $\left.\mu \mathrm{M}\right)$, (E) LysoTracker Red ${ }^{(\mathbb{R}}$ (75 nM), (F) overlay of $D$ and $E$. 
induced disruption of the vesicles. Breakage of vesicles due to incubation with FM4-46 ${ }^{\mathbb{R}}$ was not seen by us with previous tested bioconjugates and shows the sensitivity of the cells towards the ferrocene containing polyarginine $(2,5)$, not be seen with other ferrocene conjugates. ${ }^{35}$

Partial colocalization was observed with LysoTracker Red ${ }^{\circledR}$ (Fig. 4D-F). No light induced disruption was visible by confocal microscopy. We observed leakage of vesicles in the fluorescence microscopy after $14 \mathrm{~h}$ incubation, however, not by using confocal microscopy after $2 \mathrm{~h}$ incubation. This might originate from the different incubation times and light intensity/energy. In conclusion we can observe enhanced leakage for metallocene conjugates, as well as enhanced photoinduced breakage of vesicles by coupling of ferrocene and ruthenocene and enhanced chemical induced breakage for ferrocene polyarginine.

Cytotoxicity. The cytotoxicity was determined by two different assays, the resazurin and crystal violet assay. ${ }^{43-45}$ Bioconjugates 1,2 and 3 were tested in the range of $1 \mu \mathrm{M}$ to $1 \mathrm{mM}$. To distinguish the metal-based cytotoxicity, the metal-free peptide (1) was studied as well as the metallocene carboxylic acids $\left(\mathrm{CpFeC}_{5} \mathrm{H}_{4} \mathrm{COOH}\right.$ and $\left.\mathrm{CpRuC}_{5} \mathrm{H}_{4} \mathrm{COOH}\right)$. Metallocene carboxylic acids revealed no antiproliferative effect on all three cell lines up to the tested concentration of $1 \mathrm{mM}$. In the literature, the antiproliferative activity of polyarginine peptides has been discussed controversally. ${ }^{46-48}$ However, in our studies, the peptide shows a very low activity on all three tested cell lines, revealing $\mathrm{IC}_{50}$ values between $200-300 \mu \mathrm{M}$ in both assays (see Table 1 and Table S1, ESI $\dagger$ ).

This antiproliferative effect was increased by functionalization of the peptide with the metallocenes ruthenocene or ferrocene $(3,2)$ by $2-4$-fold. Interestingly, the enhanced toxicity is dependent on the metallocene coupled to the peptide. Both metallocenes do enhance the bioconjugates' lipophilicity and therefore expected unspecific uptake in a comparable way, as shown by HPLC retention times as well as previous $\log P$ experiments on metallocene peptide bioconjugates. ${ }^{35}$ Nevertheless, both bioconjugates show a distinct difference (around 1.5-fold) in their toxicity. This result either indicates a higher cellular uptake of the toxic polyarginine peptide sequence by coupling to ferrocene- over ruthenocene or an additional cytotoxic effect originating from the ferrocene moiety such as enhanced ROS production for example due to the ability of iron(II) center in ferrocene to undergo Fenton chemistry directly as shown by Osella and coworkers. ${ }^{49}$

Induction of apoptosis. In the past, compounds inducing LMP have been reported to result in necrosis and therefore, have not been considered as candidates for anticancer therapy.

Table $1 \quad I_{50}$ values, crystal violet assay after $48 \mathrm{~h}$

\begin{tabular}{lccc}
\hline Compound & HeLa $[\mu \mathrm{M}]$ & PT45 $[\mu \mathrm{M}]$ & HepG2 $[\mu \mathrm{M}]$ \\
\hline $\mathbf{1}$ & $179 \pm 36$ & $246 \pm 39$ & $291 \pm 38$ \\
$\mathbf{2}$ & $48 \pm 9$ & $92 \pm 14$ & $69 \pm 7$ \\
$\mathbf{3}$ & $70 \pm 9$ & $124 \pm 22$ & $102 \pm 12$ \\
FcC(O)OH, RcC(O)OH & $>1000$ & $>1000$ & $>1000$ \\
Cisplatin & $1.3 \pm 0.2$ & $0.9 \pm 0.2$ & $2.4 \pm 0.4$
\end{tabular}

More recent research reveals apoptosis induction by these compounds concomitant with necrosis present only when massive leakage of the lysosomes occurs. Consequently, the measurement of apoptosis is an important factor for the evaluation of these compounds towards development as anticancer drugs.

HeLa cells were treated for $48 \mathrm{~h}$ with indicated concentrations of compounds 1, 2 and 3, and flow cytometry analysis upon Annexin V/propidium iodide (AnnV/PI) staining was performed. AnnV staining indicates apoptototic cells, whereas propidium iodide stains only dead cells/necrotic cells. Single staining of AnnV reveals early apoptosis, combined AnnV-PI coloring shows late apoptosis whereas PI staining alone reveals necrosis due to complete cell membrane destruction. As shown in Fig. 5, none of the tested compounds induce necrosis. Depending on their antiproliferative activity the compounds promote early and late apoptosis. For the metal free bioconjugate 1, most cells are still viable even at a fairly high concentration of $300 \mu \mathrm{M}$, whereas upon treatment with $200 \mu \mathrm{M}$ of the ruthenocene derivative $\mathbf{3}$ most cells are dead or are in the stage of late apoptosis. The iron containing compound 2 , the most active compound of this series shows mainly late apoptosis already at a concentration of $100 \mu \mathrm{M}$ also without inducing necrosis. Even at those high concentrations there is no sign of necrosis induction (see also Fig. S6, ESI $\dagger$ ).

ROS formation. An important parameter for LMP is ROS formation since it causes a destabilization of the membrane lipids which in turn leads to an increased vesicular vulnerability. Furthermore, an increased intracellular ROS level leads to apoptosis due to DNA damage and also destabilization of the intracellular redox balance, which might start a redoxdependent signaling cascade and finally results in LMP. ${ }^{3-7}$ All these facts identify ROS as important mediators for apoptosis and LMP. Especially iron complexes increase the lysosomal vulnerability due to their influence upon intracellular redox balance. $^{6,7}$

The intracellular ROS level of 1, 2 and 3 were quantified upon treatment of HeLa cells (Fig. 6). Cells were treated with indicated concentrations of the compound and the intracellular ROS levels were measured after $48 \mathrm{~h}$ using flow cytometry upon dihydroethidium staining.

The metal free reference compound $\mathbf{1}$ does not induce ROS formation compared to the non treated cells (NT). However, the metallocene-polyarginine bioconjugates $(2,3)$ clearly reveal an enhanced intracellular ROS induction. As expected the iron containing bioconjugate 2 shows the highest ROS formation of the three tested compounds. Whether this is the consequence of the higher toxicity and therefore only a secondary effect of a higher apoptosis induction or whether this result is primarily due to the redox chemistry of the iron of the ferrocene head group itself is not clear and needs further investigation. For compound 3, no redox activity is expected of the $\mathrm{Ru}(\mathrm{II})$ under the intracellular condition present. Therefore, here the increase in ROS seems to be the result of the induced apoptosis. Compound 2 exhibits a two times higher ROS induction than 3 which is in agreement with the antiproliferative activity of the compounds and therefore, seems to be a secondary effect of the 


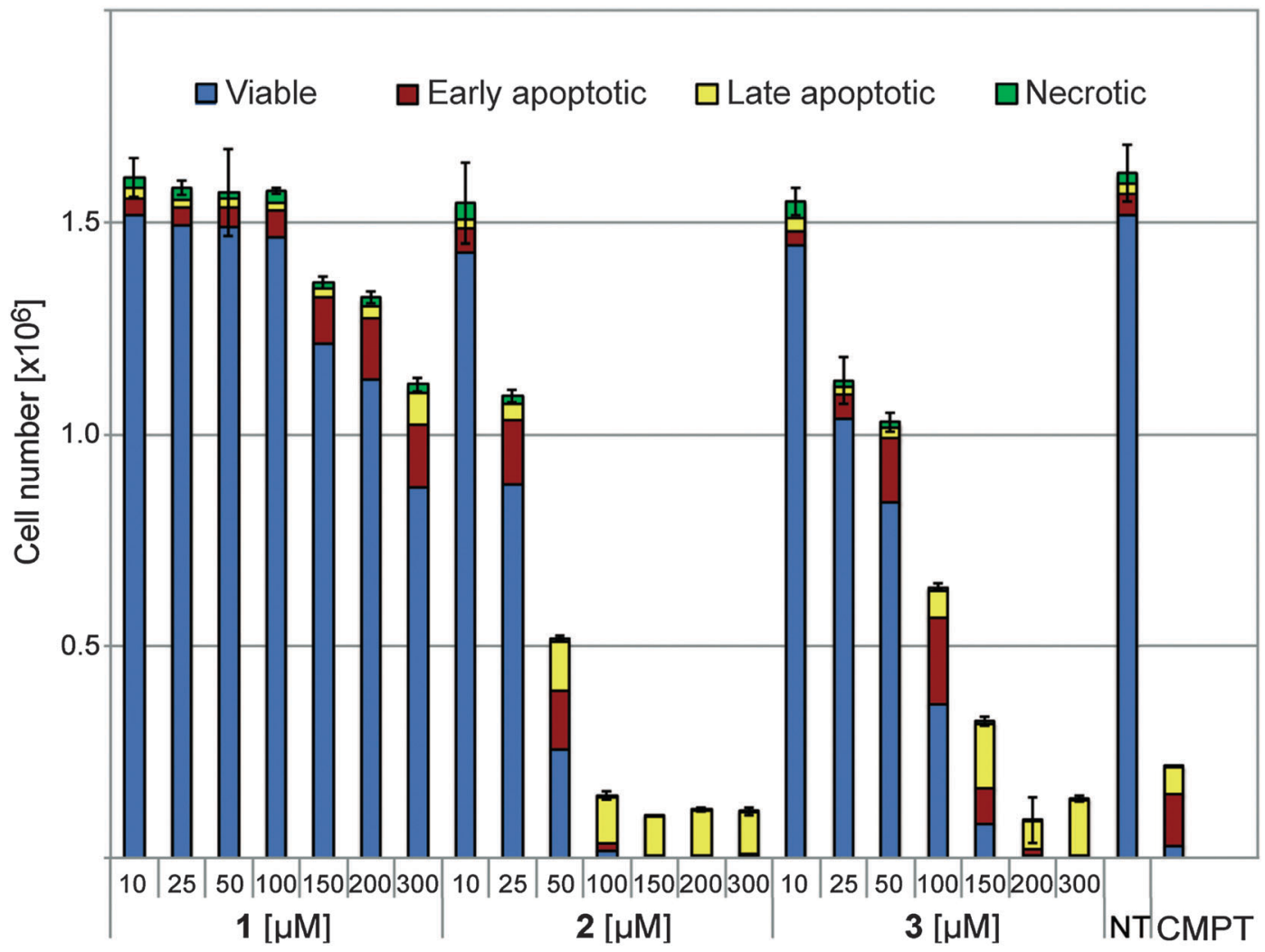

Fig. 5 Apoptosis induction of $\mathbf{1}, \mathbf{2}$ and $\mathbf{3}$ in HeLa cells at the indicated concentrations after $48 \mathrm{~h}$.

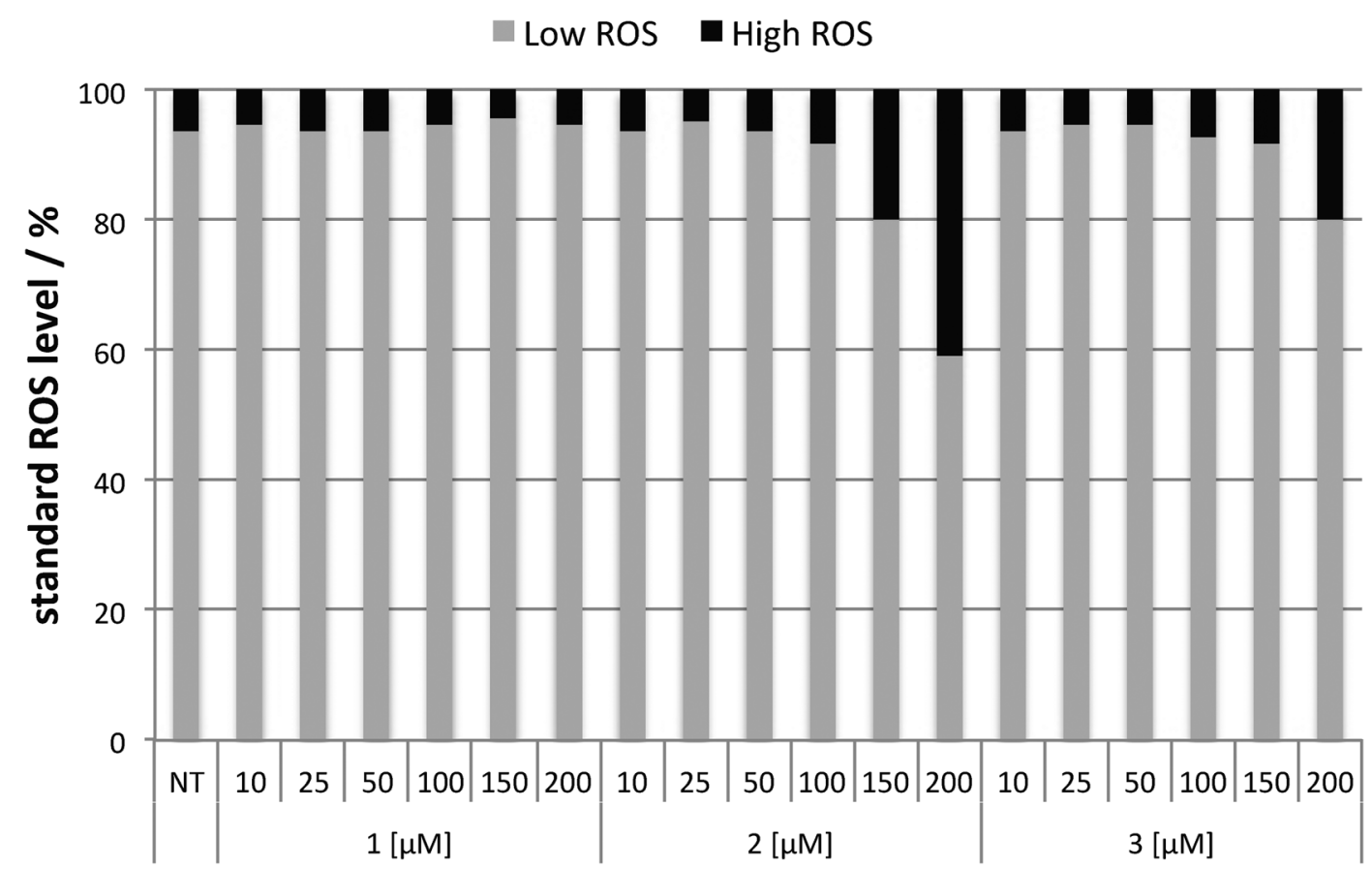

Fig. 6 Intracellular ROS level of HeLa cells treated with 1, 2 and 3 at indicated concentrations for $48 \mathrm{~h}$.

apoptosis. This assumption is consistent with the rather high concentration needed to induce ROS formation in relation to the $\mathrm{IC}_{50}$ values.
Cell cycle. In comparison to non-treated HeLa cells our data seem to indicate that slightly more cells are in the S- and G2/M phase whereas consequently a lower percentage of cells are 
(a) generation. (b)

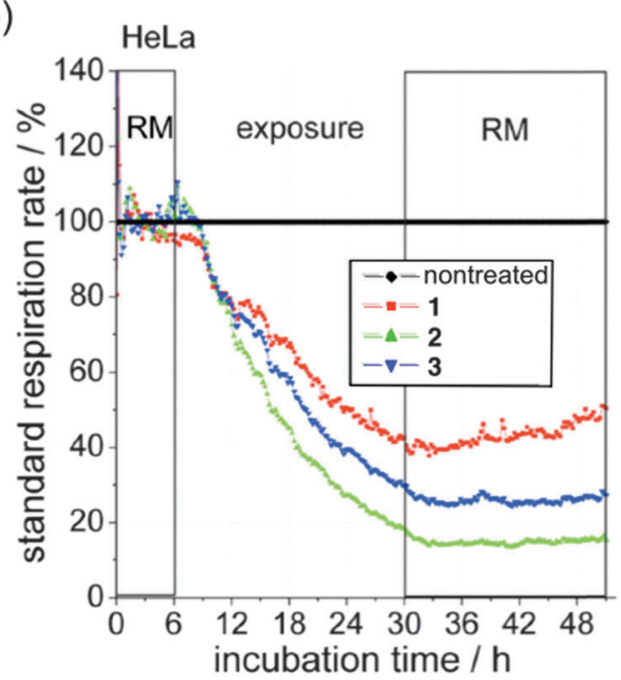

Fig. 7 (a) Standard acidification and (b) standard respiration rate of 1, 2 and $\mathbf{3}$ (100 $\mu$ M) in HeLa cells.

present in the G1 phase (see Fig. S7, ESI $\dagger$ ). The G2/M arrest might be correlated with DNA damage as a consequence of ROS

BIONAS assay. The standard acidification and respiration rates were measured in real-time in HeLa cells for $24 \mathrm{~h}$ (Fig. 7).

The result reveals a negative influence of 1,2 and 3 (at concentrations of $100 \mu \mathrm{M}$ ) towards the respiration and acidification resulting from an almost immediate inhibition of glycolysis and respiration. However, the way the respiration as well as glycolysis have been effected shows a general toxicity rather than a direct block of the energy production. Moreover the ferrocene compound (2) and to a lesser degree also the ruthenocene derivative (3) reveal an enhanced distortion of the energy production compared to the metal free compound 1. Interestingly, after removal of the metal free compound $\mathbf{1}$, the cells show a rapid recovery especially in the acidification rate and a slower but constant recovery of the respiration rate. However, compound 3 reveals only a weak recovery of the acidification whereas 2 shows no recovery of the cells at all after compound removal.

\section{Discussion}

An important matter of discussion is the origin of the antiproliferative activity in poly-Arg peptides. A review of the literature reveals that the toxicity of polyarginine itself is discussed controversially. $^{46-48}$ Previously, Miklan et al. reported a ferrocenoyl-polyarginine compound with a slightly modified polyarginine sequence than the here presented ferrocenoylpolyarginine $2 .{ }^{48}$ This already published ferrocene conjugate has shown a comparable toxicity to 2 , but the origin of its activity was assumed to be due to the ferrocene functionalization. In their study the unmodified peptide revealed no cytotoxic effect up to a concentration of $10 \mathrm{mM}$. However, in our study also the polyarginine sequence alone reveals a weak but distinct activity.

For our system, we propose that the bioconjugate's toxicity is not based on the ferrocene or ruthenocene moieties, which is in agreement with the lack of an antiproliferative effect of our previously studied ruthenocenoyl and monosubstituted ferrocenoyl peptides and PNA bioconjugates. ${ }^{32,33,35}$

More likely, the cytotoxicity is the result of a higher uptake of the weakly active polyarginine peptide when coupled to a metallocene. Both metallocenes are not charged to contribute to the electrostatic binding mode of polyarginine, but both metallocenes do enhance the bioconjugates' lipophilicity in a comparable way, as shown by their HPLC retention times. Nevertheless, they show a distinct difference (around 1.5-fold) in their toxicity. This either indicates a superior uptake of ferrocene over ruthenocene or an additional cytotoxic effect of ferrocene, for example enhanced ROS production due to its ability to undergo Fenton chemistry. In our studies we observed an increased uptake for both metallocene conjugates (ruthenocene $<$ ferrocene) in comparison to the acetylated peptide as evaluated by fluorescence microscopy (Fig. S5, ESI $\dagger$ ). This result is supported by previous uptake studies, where we could show that ferrocene-derivatized PNA reveals an enhanced uptake (by a factor of $c a$. 4) over its ruthenocene analogue in HT-29 cells, quantified by an AAS study. ${ }^{32}$ Therefore, the higher cytotoxic activity is probably an indicator for metallocene-enhanced uptake rather than for metal-based toxicity.

If we assume that the toxicity of the peptide is dependent only on the intracellular compound concentration with no additional cytotoxic effect, we can postulate from the $\mathrm{IC}_{50}$ values a semi-quantitative value of 2 - to 3 -fold enhanced uptake of 3 by the ruthenocene headgroup compared to $\mathbf{1}$. For ferrocene, we can expect an iron based enhancement of the toxicity due to its redox properties and therefore, an enhanced ROS production followed by enhanced lysosomal leakage. Here, the comparison of uptake and cytotoxicity might be more intricate.

\section{Conclusion}

In this study, a series of metallocene polyarginine bioconjugates was synthesized by Fmoc-SPPS to investigate their potential to 
disrupt lysosomal membranes and to act as LMP inducing compounds. LMP inducing compounds have been proposed as interesting compounds for tumor targeting by releasing cathepsins and induce a number of apoptotic stimuli. Metallocene bioconjugates as well as their fluorophore-labelled derivatives containing the ferrocene or ruthenocene headgroup were successfully synthesized and compared to the acetylated, metal free peptide regarding their potential to induce LMP. In addition to ferrocene-peptide conjugates, this paper also reports the synthesis of the first conjugates of ruthenocene with cell penetrating peptide derivatives.

To investigate their biological behaviour the compounds were tested on an artificial mammalian membrane, but no membranolytic activity could be observed. This finding supports a lysosomal disruption based on the basic guanidine residues of the polyarginine peptide due to protonation inside the more acidic lysosomes. However, increased vulnerability of vesicles could be shown by fluorescence microscopy by photo- as well as chemical-induced leakage. This increased vulnerability was found to be concentration dependent (between 10-50 $\mu \mathrm{M}$ ). That the compounds actually reach lysosomes could be shown by fluorescence microscopy co-localization studies of the ferrocene peptide $\mathbf{5}$ which revealed a vesicular distribution and at least a partial localization in lysosomes. By visual inspection the best cellular uptake of all tested compounds was observed for the ferrocene conjugate over ruthenocene and the metal free derivatives. Furthermore, this differential uptake, in the order ferrocenoyl- $>$ ruthenocenoyl- $>$ acetyl-polyarginine, also correlates with the toxicity of the compounds. As shown by the crystal violet antiproliferative assay, ferrocene increases the antiproliferative activity of polyarginines around 3-4-fold and ruthenocene by 2-3fold, depending on the cell line, and compared to the acetylated, but metal-free compound 1. After finding an increased vulnerability of vesicles which correlates with toxicity we were interested to get more detailed insights into the biological effects of these compounds, notably in induction of apoptosis and/or necrosis since both have been reported to be effects of LMP. In our assays no increased necrosis compared to the non-treated cells was observed, while especially 2 and 3 show strong induction of apoptosis. ROS induction and cell cycle arrest revealed only minor changes, which might be a secondary effect of apoptosis induction. The biological activity of metallocene-polyarginine conjugates is also reflected in other experiments such as respiration and acidification rate. Here, the metal-free compound (1) shows minor activity compared to the metal containing conjugates with a rapid recovery after compound removal, whereas 2 and 3 reveal higher activity, with no or only weak recovery.

All taken together, the metallocene-polyarginine bioconjugates 2 and 3 clearly enhance the properties of the metal-free compound 1 regarding their antiproliferative and lysosomal destabilizing properties and therefore, we propose these compounds as interesting candidates for the development of lysosomal targeting anticancer drugs.

\section{Acknowledgements}

This research was supported by the German Research Foundation (DFG) through the Research Unit "Biological Function of
Organometallic compounds" (FOR 630, www.rub.de/for630) and the Cluster of Excellence RESOLV (EXC 1069). A.G. thanks Joachim Lügger for synthesizing ruthenocene carboxylic acid, the RUB Research School for further financial support, and Prof. Hahn for permission to use cell culture facilities in their lab.

\section{References}

1 L. Groth-Pedersen and M. Jaattela, Combating apoptosis and multidrug resistant cancers by targeting lysosomes, Cancer Lett., 2013, 332, 265-274.

2 A.-C. Johansson, H. Appelqvist, C. Nilsson, K. Kagedal, K. Roberg and K. Oellinger, Regulation of apoptosis-associated lysosomal membrane permeabilization, Apoptosis, 2010, 15, 527-540.

3 B. Garner, W. Li, K. Roberg and U. T. Brunk, On the cytoprotective role of ferritin in macrophages and its ability to enhance lysosomal stability, Free Radical Res., 1997, 27, 487-500.

4 H. L. Persson, K. J. Nilsson and U. T. Brunk, Novel cellular defenses against iron and oxidation: Ferritin and autophagocytosis preserve lysosomal stability in airway epithelium, Redox Rep., 2001, 6, 57-63.

5 H. L. Persson, T. Kurz, J. W. Eaton and U. T. Brunk, Radiation-induced cell death: Importance of lysosomal destabilization, Biochem. J., 2005, 389, 877-884.

6 H. L. Persson, Z. Yu, O. Tirosh, J. W. Eaton and U. T. Brunk, Prevention of oxidant-induced cell death by lysosomotropic iron chelators, Free Radical Biol. Med., 2003, 34, 1295-1305.

7 Z. Yu, H. L. Persson, J. W. Eaton and U. T. Brunk, Intralysosomal iron: A major determinant of oxidant-induced cell death, Free Radical Biol. Med., 2003, 34, 1243-1252.

8 K. Kagedal, M. Zhao, I. Svensson and U. T. Brunk, Sphingosine-induced apoptosis is dependent on lysosomal proteases, Biochem. J., 2001, 359, 335-343.

9 H.-F. Zhao, X. Wang and G.-J. Zhang, Lysosome destabilization by cytosolic extracts, putative involvement of $\mathrm{Ca}^{2+} /$ phospholipase C, FEBS Lett., 2005, 579, 1551-1556.

10 G. Zhang, Y.-P. Yi and G.-J. Zhang, Effects of arachidonic acid on the lysosomal ion permeability and osmotic stability, J. Bioenerg. Biomembr., 2006, 38, 75-82.

11 J.-S. Hu, Y.-B. Li, J.-W. Wang, L. Sun and G.-J. Zhang, Mechanism of lysophosphatidylcholine-induced lysosome destabilization, J. Membr. Biol., 2007, 215, 27-35.

12 Y. P. Yi, X. Wang, G. Zhang, T. S. Fu and G. J. Zhang, Phosphatidic acid osmotically destabilizes lysosomes through increased permeability to $\mathrm{K}^{+}$and $\mathrm{H}^{+}$, Gen. Physiol. Biophys., 2006, 25, 149-160.

13 J. A. Joyce, A. Baruch, K. Chehade, N. Meyer-Morse, E. Giraudo, F.-Y. Tsai, D. C. Greenbaum, J. H. Hager, M. Bogyo and D. Hanahan, Cathepsin cysteine proteases are effectors of invasive growth and angiogenesis during multistage tumorigenesis, Cancer Cell, 2004, 5, 443-453.

14 T. Kirkegaard and M. Jaeaettelae, Lysosomal involvement in cell death and cancer, Biochim. Biophys. Acta, Mol. Cell Res., 2009, 1793, 746-754. 
15 N. Fehrenbacher, L. Bastholm, T. Kirkegaard-Sorensen, B. Rafn, T. Bottzauw, C. Nielsen, E. Weber, S. Shirasawa, T. Kallunki and M. Jaeaettelae, Sensitization to the lysosomal cell death pathway by oncogene-induced down-regulation of lysosome-associated membrane proteins 1 and 2, Cancer Res., 2008, 68, 6623-6633.

16 E. Vives, P. Brodin and B. Lebleu, A truncated HIV-1 Tat protein basic domain rapidly translocates through the plasma membrane and accumulates in the cell nucleus, J. Biol. Chem., 1997, 272, 16010-16017.

17 P. M. Fischer, E. Krausz and D. P. Lane, Cellular delivery of impermeable effector molecules in the form of conjugates with peptides capable of mediating membrane translocation, Bioconjugate Chem., 2001, 12, 825-841.

18 S. Futaki, T. Suzuki, W. Ohashi, T. Yagami, S. Tanaka, K. Ueda and Y. Sugiura, Arginine-rich peptides: An abundant source of membrane-permeable peptides having potential as carriers for intracellular protein delivery, J. Biol. Chem., 2001, 276, 5836-5840.

19 A. Berchanski and A. Lapidot, Bacterial RNAse P RNA is a drug target for aminoglycoside-arginine conjugates, Bioconjugate Chem., 2008, 19, 1896-1906.

20 S. R. Schwarze, A. Ho, A. Vocero-Akbani and S. F. Dowdy, In vivo protein transduction: Delivery of a biologically active protein into the mouse, Science, 1999, 285, 1569-1572.

21 J. B. Rothbard, E. Kreider, K. Pattabiraman, E. T. Pelkey, C. L. VanDeusen, L. Wright, B. L. Wylie and P. A. Wender, Arginine-rich molecular transporters for drugs: The role of backbone and side chain variations on cellular uptake, Cell-Penetrating Pept., 2002, 141-160.

22 J. P. Richard, K. Melikov, E. Vives, C. Ramos, B. Verbeure, M. J. Gait, L. V. Chernomordik and B. Lebleu, Cell-penetrating peptides, J. Biol. Chem., 2003, 278, 585-590.

23 S. M. Fuchs and R. T. Raines, Polyarginine as a multifunctional fusion tag, Protein Sci., 2005, 14, 1538-1544.

24 S. M. Fuchs and R. T. Raines, Pathway for polyarginine entry into mammalian cells, Biochemistry, 2004, 43, 2438-2444.

25 G. Gasser, I. Ott and N. Metzler-Nolte, Organometallic anticancer compounds, J. Med. Chem., 2011, 54, 3-25.

26 G. Gasser and N. Metzler-Nolte, The potential of organometallic complexes in medicinal chemistry, Curr. Opin. Chem. Biol., 2012, 16, 84-91.

27 C. G. Hartinger, N. Metzler-Nolte and P. J. Dyson, Challenges and opportunities in the development of organometallic anticancer drugs, Organometallics, 2012, 31, 5677-5685.

28 F. Noor, A. Wuestholz, R. Kinscherf and N. Metzler-Nolte, A cobaltocenium-peptide bioconjugate shows enhanced cellular uptake and directed nuclear delivery, Angew. Chem., Int. Ed., 2005, 44, 2429-2432.

29 E. Hillard, A. Vessieres, L. Thouin, G. Jaouen and C. Amatore, Ferrocene-mediated proton-coupled electron transfer in a series of ferrocifen-type breast-cancer drug candidates, Angew. Chem., Int. Ed., 2006, 45, 285-290.

30 C. Biot, F. Nosten, L. Fraisse, D. Ter-Minassian, J. Khalife and D. Dive, The antimalarial ferroquine: From bench to clinic, Parasite, 2011, 18, 207-214.
31 A. Gross and N. Metzler-Nolte, Synthesis and characterization of a ruthenocenoyl bioconjugate with the cyclic octapeptide octreotate, J. Organomet. Chem., 2009, 694, 1185-1188.

32 A. Gross, N. Huesken, J. Schur, L. Raszeja, I. Ott and N. Metzler-Nolte, A ruthenocene-PNA bioconjugate - synthesis, characterization, cytotoxicity and AAS-detected cellular uptake, Bioconjugate Chem., 2012, 23, 1764-1774.

33 A. Gross, M. Neukamm and N. Metzler-Nolte, Synthesis and cytotoxicity of a bimetallic ruthenocene dicobalthexacarbonyl alkyne peptide bioconjugate, Dalton Trans., 2011, 40, 1382-1386.

34 M. Patra and N. Metzler-Nolte, Azidomethyl-ruthenocene: Facile synthesis of a useful metallocene derivative and its application in the 'click' labelling of biomolecules, Chem. Commun., 2011, 47, 11444-11446.

35 A. Gross, D. Habig and N. Metzler-Nolte, Synthesis and structure-activity relationship study of organometallic bioconjugates of the cyclic octapeptide octreotate, ChemBioChem, 2013, 14, 2472-2479.

36 H. M. Moulton, M. H. Nelson, S. A. Hatlevig, M. T. Reddy and P. L. Iversen, Cellular uptake of antisense morpholino oligomers conjugated to arginine-rich peptides, Bioconjugate Chem., 2004, 15, 290-299.

37 G. A. McCubbin, S. Praporski, S. Piantavigna, D. Knappe, R. Hoffmann, J. H. Bowie, F. Separovic and L. L. Martin, QCM-D fingerprinting of membrane-active peptides, Eur. Biophys. J., 2011, 40, 437-446.

38 S. Piantavigna, G. A. McCubbin, S. Boehnke, B. Graham, L. Spiccia and L. L. Martin, A mechanistic investigation of cellpenetrating Tat peptides with supported lipid membranes, Biochim. Biophys. Acta, Biomembr., 2011, 1808, 1811-1817.

39 H. Alborzinia, S. Can, P. Holenya, C. Scholl, E. Lederer, I. Kitanovic and S. Woelfl, Real-time monitoring of cisplatin-induced cell death, PLoS One, 2011, 6, e19714.

40 S.-R. Ji, Y. Wu and S.-F. Sui, Cholesterol is an important factor affecting the membrane insertion of $\beta$-amyloid peptide (A $\beta 1-40)$, which may potentially inhibit the fibril formation, J. Biol. Chem., 2002, 277, 6273-6279.

41 P. Czihal, D. Knappe, S. Fritsche, M. Zahn, N. Berthold, S. Piantavigna, U. Mueller, S. Van Dorpe, N. Herth, A. Binas, G. Koehler, B. De Spiegeleer, L. L. Martin, O. Nolte, N. Straeter, G. Alber and R. Hoffmann, Api88 is a novel antibacterial designer peptide to treat systemic infections with multidrug-resistant gram-negative pathogens, ACS Chem. Biol., 2012, 7, 1281-1291.

42 F. Noor, R. Kinscherf, G. A. Bonaterra, S. Walczak, S. Woelfl and N. Metzler-Nolte, Enhanced cellular uptake and cytotoxicity studies of organometallic bioconjugates of the NLS peptide in Hep G2 cells, ChemBioChem, 2009, 10, 493-502.

43 J. O'Brien, I. Wilson, T. Orton and F. Pognan, Investigation of the alamar blue (resazurin) fluorescent dye for the assessment of mammalian cell cytotoxicity, Eur. J. Biochem., 2000, 267, 5421-5426.

44 R. J. Gillies, N. Didier and M. Denton, Determination of cell number in monolayer cultures, Anal. Biochem., 1986, 159, 109-113. 
45 Y.-I. Yang, D.-W. Jung, D.-G. Bai, G.-S. Yoo and J.-K. Choi, Counterion-dye staining method for DNA in agarose gels using crystal violet and methyl orange, Electrophoresis, 2001, 22, 855-859.

46 S. W. Jones, R. Christison, K. Bundell, C. J. Voyce, S. M. V. Brockbank, P. Newham and M. A. Lindsay, Characterization of cell-penetrating peptide-mediated peptide delivery, Br. J. Pharmacol., 2005, 145, 1093-1102.

47 K. H. Ko, C. J. Lee, C. Y. Shin, M. Jo and K. C. Kim, Inhibition of mucin release from airway goblet cells by polycationic peptides, Am. J. Physiol.: Lung Cell. Mol. Physiol., 1999, 277, 811-815.

48 Z. Miklan, R. Szabo, V. Zsoldos-Mady, J. Remenyi, Z. Banoczi and F. Hudecz, New ferrocene containing peptide conjugates: Synthesis and effect on human leukemia (HL-60) cells, Biopolymers, 2007, 88, 108-114.

49 D. Osella, M. Ferrali, P. Zanello, F. Laschi, M. Fontani, C. Nervi and G. Cavigiolio, On the mechanism of the antitumor activity of ferrocenium derivatives, Inorg. Chim. Acta, 2000, 306, 42-48. 